\title{
Global cloud condensation nuclei influenced by carbonaceous combustion aerosol
}

\author{
D. V. Spracklen ${ }^{1}$, K. S. Carslaw ${ }^{1}$, U. Pöschl ${ }^{2}$, A. Rap ${ }^{1}$, and P. M. Forster ${ }^{1}$ \\ ${ }^{1}$ Institute for Climate and Atmospheric Science, School of Earth and Environment, University of Leeds, Leeds, UK \\ ${ }^{2}$ Biogeochemistry Department, Max Planck Institute for Chemistry, Mainz, Germany
}

Received: 4 February 2011 - Published in Atmos. Chem. Phys. Discuss.: 1 March 2011

Revised: 16 June 2011 - Accepted: 22 August 2011 - Published: 5 September 2011

\begin{abstract}
Black carbon in carbonaceous combustion aerosol warms the climate by absorbing solar radiation, meaning reductions in black carbon emissions are often perceived as an attractive global warming mitigation option. However, carbonaceous combustion aerosol can also act as cloud condensation nuclei $(\mathrm{CCN})$ so they also cool the climate by increasing cloud albedo. The net radiative effect of carbonaceous combustion aerosol is uncertain because their contribution to $\mathrm{CCN}$ has not been evaluated on the global scale. By combining extensive observations of CCN concentrations with the GLOMAP global aerosol model, we find that the model is biased low (normalised mean bias $=-77 \%$ ) unless carbonaceous combustion aerosol act as $\mathrm{CCN}$. We show that carbonaceous combustion aerosol accounts for more than half (52-64\%) of global CCN with the range due to uncertainty in the emitted size distribution of carbonaceous combustion particles. The model predicts that wildfire and pollution (fossil fuel and biofuel) carbonaceous combustion aerosol causes a global mean cloud albedo aerosol indirect effect of $-0.34 \mathrm{~W} \mathrm{~m}^{-2}$, with stronger cooling if we assume smaller particle emission size. We calculate that carbonaceous combustion aerosol from pollution sources cause a global mean aerosol indirect effect of $-0.23 \mathrm{~W} \mathrm{~m}^{-2}$. The small size of carbonaceous combustion particles from fossil fuel sources means that whilst pollution sources account for only onethird of the emitted mass they cause two-thirds of the cloud albedo aerosol indirect effect that is due to carbonaceous combustion aerosol. This cooling effect must be accounted for, along with other cloud effects not studied here, to ensure that black carbon emissions controls that reduce the high number concentrations of fossil fuel particles have the desired net effect on climate.
\end{abstract}

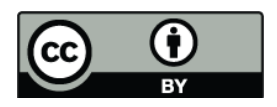

Correspondence to: D. V. Spracklen (dominick@env.leeds.ac.uk)

\section{Introduction}

Carbonaceous combustion aerosol are particles that are emitted into the atmosphere during fossil fuel combustion, biofuel combustion and open biomass burning. Previous assessments have concluded that the black carbon (BC) in carbonaceous combustion aerosol warms the climate (Jacobson, 2001; Chung and Seinfeld, 2002; Chung et al., 2005; Sato et al., 2003; Hansen et al., 2007, Forster et al., 2007; Ramanathan and Carmichael, 2009), making reductions in BC emissions an attractive global warming mitigation option (Jacobson, 2002; Bond and Sun, 2005; Bond, 2007; Grieshop et al., 2009; Arneth et al., 2009; Rypdal et al., 2009; Quinn et al., 2008). BC is a strong absorber of solar and infrared radiation and has been estimated to cause a globally averaged positive direct radiative forcing of $0.25-0.44 \mathrm{~W} \mathrm{~m}^{-2}$ in model studies (Schulz et al., 2006) and up to $0.9 \mathrm{~W} \mathrm{~m}^{-2}$ when constrained by observations (Chung et al., 2005; Ramanathan and Carmichael, 2009), up to half of the forcing due to $\mathrm{CO}_{2}$. $\mathrm{BC}$ also causes warming by reducing snow albedo, estimated as $0.1 \pm 0.1 \mathrm{~W} \mathrm{~m}^{-2}$ (Forster et al., 2007). It has been suggested that reductions in $\mathrm{BC}$ emissions could slow global warming and its complete elimination would reduce global average surface temperatures by $0.5-1.0^{\circ} \mathrm{C}$ (Ramanathan and Carmichael, 2009).

However, carbonaceous combustion aerosol also contains particulate organic matter (POM), which can have a cooling effect on climate because it scatters solar radiation (Schulz et al., 2006) and can enable carbonaceous combustion aerosol to act as cloud condensation nuclei $(\mathrm{CCN})$ and form cloud drops, increasing cloud albedo (Chuang et al., 2002; Lohmann et al., 2000) - the so-called first aerosol indirect effect (AIE). Some studies have estimated a global cloud albedo forcing of $-0.5 \mathrm{~W} \mathrm{~m}^{-2}$ and predict net positive forcing (Hansen et al., 2005, 2007), while others suggest a large cloud albedo forcing of between $-0.9 \mathrm{~W} \mathrm{~m}^{-2}$ (Lohmann et al., 2000) and $-1.68 \mathrm{~W} \mathrm{~m}^{-2}$ (Chuang et al., 2002) potentially

Published by Copernicus Publications on behalf of the European Geosciences Union. 
sufficient to produce a net negative forcing due to carbonaceous combustion aerosol.

Additionally, carbonaceous combustion aerosol affect clouds through a range of mechanisms including semi-direct effects (Hansen et al., 1997), the cloud absorption effect (Jacobson 2002, 2010) and potentially through acting as ice nuclei (e.g., DeMott et al., 1999). The semi-direct effect is used to describe the range of cloud responses that occur due to changes in the temperature structure of the atmosphere driven by absorbing aerosols. Koch and Del Genio (2010) reviewed model studies of the semi-direct effect and showed that the net-negative semi-direct effect due to BC may be similar in magnitude but opposite in sign to the positive direct effect of $\mathrm{BC}$. The climate response due to $\mathrm{BC}$ also critically depends on the vertical profile of the aerosol, with $\mathrm{BC}$ resulting in less warming when present at higher altitudes (e.g., Ban-Weiss et al., 2011). Jacobson (2002, 2004, 2006, 2010) account for a diverse range of aerosol-climate interactions including the aerosol direct effect, indirect effect, semidirect effects and cloud absorption effects, and calculate a net-warming due to carbonaceous combustion aerosol.

Remote sensing studies have also been used to explore the relationship between cloud (cloud fraction and cloud optical depth) and aerosol (aerosol optical depth) properties (Koren et al., 2004; Kaufman and Koren, 2006; Ten Hoeve et al., 2011). For the Amazonian biomass burning season Tan Hoeve et al. (2011) showed that at lower values of AOD $(<0.3)$ cloud optical depth and AOD were positively correlated whereas at higher values of AOD they were negatively correlated. The authors postulated that positive correlations at low AOD may be due to the first aerosol indirect effect whereas negative correlations at high AOD may be due to inhibition of cloud development by absorbing aerosols or potentially due to satellite retrieval artifacts.

Poor understanding of the complex interactions between carbonaceous combustion aerosol and clouds has forced many previous studies to account only for atmospheric BC heating when assessing the global warming potential of carbonaceous combustion aerosol (Bond and Sun, 2005; Grieshop et al., 2009). However, it is not possible to quantify the global warming potential or to understand the climate impact of particulate control strategies aimed at BC without understanding the net effect of the particles on clouds.

The cloud condensation nuclei (CCN) number concentration is the fundamental quantity determining the impact of aerosol particles on cloud drop number concentrations (CDNC) and cloud albedo. CCN are hygroscopic particles large enough (typically $>35-50 \mathrm{~nm}$ dry diameter) to form cloud drops (Andreae and Rosenfeld, 2008). Carbonaceous combustion aerosol are known to act as CCN (Andreae et al., 2004), can account for more than half of the CCN mass in polluted regions (Hitzenberger et al., 1999) and model simulations suggest a 40-90\% contribution to the global CCN number concentration (Pierce et al., 2007) and a potentially important effect on clouds (Chen et al., 2010; Bauer et al.,
2010; Jacobson et al., 2010). However, it has not been possible to evaluate these predictions against observed $\mathrm{CCN}$ concentrations.

In this paper we investigate the impact of carbonaceous combustion aerosol on global cloud albedo. To do this we synthesise CCN observations made worldwide over the last few decades. We use a global aerosol microphysics model to make the first estimate of the contribution of carbonaceous combustion aerosol to global $\mathrm{CCN}$ that has been evaluated against observations. We use the global model to calculate the first aerosol indirect effect due to carbonaceous combustion aerosol. We do not calculate the cloud lifetime (second indirect) effect or semi-direct effects and so we are unable to estimate the full climate impact of carbonaceous combustion aerosol. The rest of the paper is structured as follows: Sect. 2 describes the CCN observations, Sect. 3 describes the aerosol model, Sect. 4 presents results and Sect. 5 conclusions.

\section{Synthesis of observed cloud condensation nuclei concentrations}

We synthesised observations of $\mathrm{CCN}$ concentrations made in 55 separate studies published in the peer-reviewed literature (Table 1). Each observation is the time-weighted mean CCN recorded at that location and represents a sampling period of days to weeks. We synthesised a total of 277 separate observations made at 80 locations around the world (Fig. 1a) by independent research groups using a variety of instruments and at a range of water vapour supersaturations $(S=0.02 \%-$ $1.5 \%)$. For measurements made above the surface we only included those made at $0-2 \mathrm{~km}$ altitude.

Our database includes measurements made from 1971 to 2009. The distribution of measurements is as follows: 19701979: 10\%; 1980-1989: 20\%; 1990-1999: 38\%; 20002009: $31 \%$, so approximately two-thirds of the observations were made since 1990. Most of the measurements have been made as part of field campaigns and report $\mathrm{CCN}$ concentrations over a sampling period of days to weeks. There is very little long-term CCN data available. Out of the $277 \mathrm{CCN}$ observations, 150 are for sampling periods of less than 10 days, and 127 are for periods of between 10 and 31 days. The observations span CCN concentrations from less than $10 \mathrm{~cm}^{-3}$ to greater than $10000 \mathrm{~cm}^{-3}$ : 98 observations report average $\mathrm{CCN}$ concentrations greater than $500 \mathrm{~cm}^{-3}$, and 179 are for $\mathrm{CCN}$ concentrations less than or equal to $500 \mathrm{~cm}^{-3}$. Observations that represent longer sampling periods are equally distributed across the range of $\mathrm{CCN}$ concentrations reported: of the 98 observations that report CCN over $500 \mathrm{~cm}^{-3}, 36$ represent more than 10 days of data. Restricting our analysis to only those observations made after 1995 or to only those observations that represent more than 10 days of data does not greatly impact our results or change our conclusions (see Table 4). Nevertheless, additional long-term observations of 
(a)

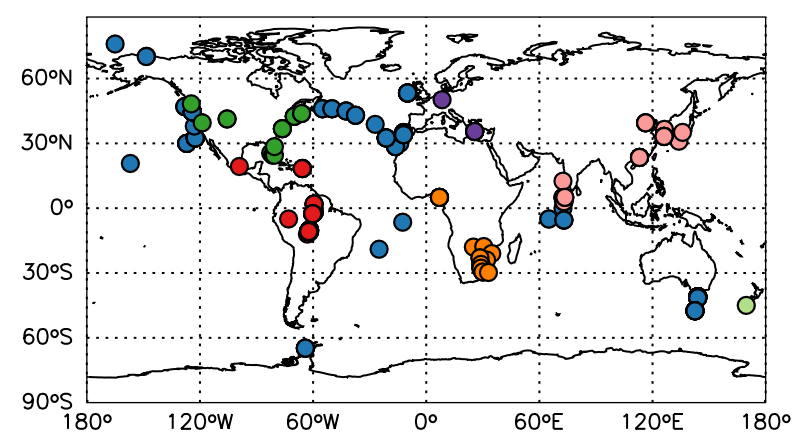

(c)

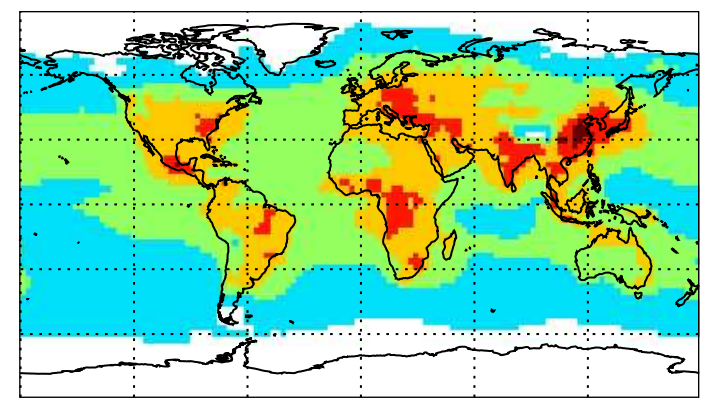

\begin{tabular}{llllllll}
\hline 10 & 31 & 100 & 316 & 1000 & 3162 & 10000 & $\mathrm{~cm}^{-3}$
\end{tabular} (b)
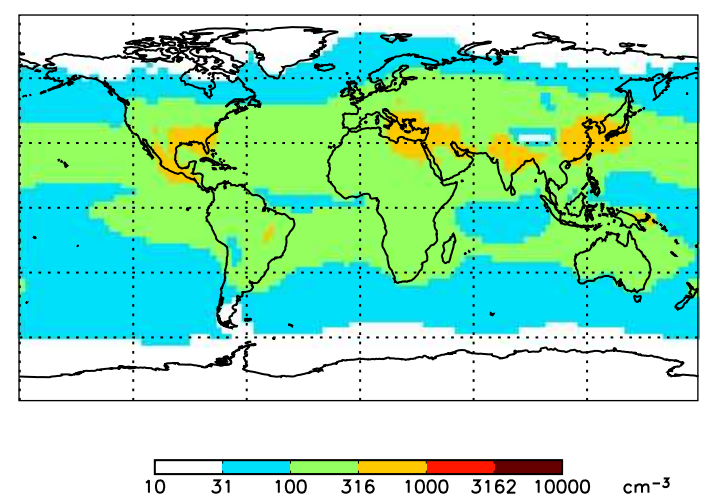

(d)

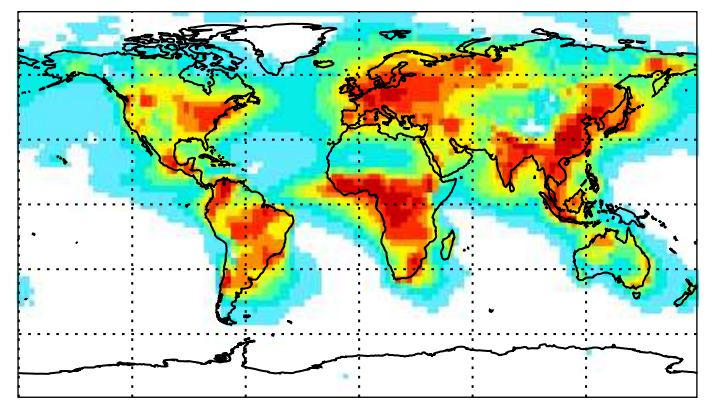

\begin{tabular}{llllllllllll}
\hline 0 & 10 & 20 & 30 & 40 & 50 & 60 & 70 & 80 & 90 & 100 & $\%$
\end{tabular}

Fig. 1. (a) Locations of the cloud condensation nuclei $(\mathrm{CCN})$ observations compiled in this analysis (colour scale matches Fig. 2a and b) and (b-d) simulated annual mean surface concentration of CCN. Model simulations are (b) without carbonaceous combustion aerosol acting as $\mathrm{CCN}$ and (c) with carbonaceous combustion aerosol acting as CCN. (d) Percentage contribution of carbonaceous combustion aerosol to CCN. CCN concentrations are calculated at $0.2 \%$ supersaturation.

$\mathrm{CCN}$ are critically needed to better constrain the contribution of carbonaceous combustion aerosol to $\mathrm{CCN}$.

The relative uncertainties of the observational data vary in the range of about 5-40\% depending on CCN concentration, supersaturation and the type of CCN instrument used (McMurry, 2000; Roberts et al., 2001, 2002, 2006; Frank et al., 2007; Rose et al., 2008). Mostly, the uncertainties were of the order of $10-20 \%$, which is consistent with the average deviations between calculations and measurements in CCN closure studies (e.g., Broekhuizen et al., 2006; Rose et al., 2010; Wang et al., 2008; Bugiatioti et al., 2009; Chang et al., 2010; Gunthe et al., 2009; Lance et al., 2009; Shantz et al., 2010; Shinozuka et al., 2009). We assume a relative uncertainty of $\pm 40 \%$ and a minimum absolute uncertainty of $\pm 20 \mathrm{~cm}^{-3}$. In any case, the uncertainties of the observational data are smaller than the large effect of carbonaceous combustion aerosol on simulated CCN concentrations.
Our synthesis substantially extends a previous compilation by Andreae (2009) who reported CCN concentrations only for $S=0.4 \%$ (or interpolated CCN observed at other supersaturations to $0.4 \%$ ). While our synthesis is focused on direct measurements of CCN concentrations, Andreae (2009) included values that were not directly observed but derived from size distribution measurements.

\section{Model description}

\subsection{GLOMAP aerosol microphysics model}

We analysed the CCN observations using the GLOMAP global aerosol microphysics model (Spracklen et al., 2005, 2008a), which is an extension of the TOMCAT 3-D global chemical transport model (Chipperfield, 2006). We simulated sulfate (SU), sea salt (SeaS), BC and POM for the year 2000. Large-scale transport and meteorology is specified from 6-hourly European Centre for Medium-Range Weather Forecasts (ECMWF) analyses. We used a horizontal 
Table 1. CCN observations (supersaturation, S) from the literature that are used in this analysis.

\begin{tabular}{|c|c|c|c|c|c|c|}
\hline Location & Latitude/Longitude & Time & $\mathrm{S}(\%)$ & CCN Instrument ${ }^{1}$ & $\begin{array}{l}\text { Platform }{ }^{2} \text {; Field Cam- } \\
\text { paign }\end{array}$ & Reference \\
\hline Japan, SW Islands & $132-136^{\circ} \mathrm{E}, 30-32^{\circ} \mathrm{N}$ & 16-28 Apr 2001 & 0.3 & TGDCC & $\begin{array}{l}\text { A; } \quad \text { APEX-E2/ACE- } \\
\text { Asia }\end{array}$ & Adhikari et al. (2005) \\
\hline South Atlantic & $40-10^{\circ} \mathrm{W}, 19^{\circ} \mathrm{S}$ & Feb-Mar 1991 & 0.3 & TGDCC & Sh & Andreae et al. (1995) \\
\hline Cape Grim, Tasmania & $144.7^{\circ} \mathrm{E}, 40.7^{\circ} \mathrm{S}$ & Long term & $0.23-1.3$ & & $\mathrm{Su}$ & $\begin{array}{l}\text { Ayers and Gras (1991); Ayers et } \\
\text { al. (1997) }\end{array}$ \\
\hline Mexico City & $99.1^{\circ} \mathrm{W}, 19.3^{\circ} \mathrm{N}$ & 13-29 Sep 2000 & 0.5 & STGDCC & $\mathrm{Su}$ & Baumgardner et al. (2004) \\
\hline Indian Ocean & $60-75^{\circ} \mathrm{E}, 15^{\circ} \mathrm{S}-15^{\circ} \mathrm{N}$ & Feb-Mar 1998 & $0.5 ; 0.75$ & CCNR & Sh; INDOEX; & Cantrell et al. (2000) \\
\hline Coastal Florida & $83-81^{\circ} \mathrm{W}, 24-27^{\circ} \mathrm{N}$ & Jun-Jul 2002 & 0.85 & CCNS & A; CRYSTAL FACE & $\begin{array}{l}\text { Conant et al. (2004); VanReken at } \\
\text { al. (2003) }\end{array}$ \\
\hline $\begin{array}{l}\text { Taunus Observatory, } \\
\text { Germany }\end{array}$ & $8.4^{\circ} \mathrm{E}, 50.2^{\circ} \mathrm{N}$ & 20 Jul-11 Aug 2004 & 0.4 & SDC & $\mathrm{Su}$ & Dusek et al. (2006) \\
\hline N. Atlantic & $75^{\circ} \mathrm{W}-37.5^{\circ} \mathrm{W}, 37-43^{\circ} \mathrm{N}$ & May 1977 & $0.16-0.85$ & $\operatorname{TGDCC}(0.2-1 \%)$, IHC $(<0.2 \%)$ & $\mathrm{Sh}$ & Hoppel (1979) \\
\hline N. Atlantic, Tenerife & $17.7-10.5^{\circ} \mathrm{W}, 28-32^{\circ} \mathrm{N}$ & Jun-Jul 1997 & 0.1 & CCNS & A, ACE-2 & Chuang et al. (2000) \\
\hline $\begin{array}{l}\text { Korea Global Atmo- } \\
\text { spheric Watch }\end{array}$ & $126.3^{\circ} \mathrm{W}, 36.5^{\circ} \mathrm{N}$ & 1-22 May 2004 & 1.0 & DRI & $\mathrm{Su}$ & Yum et al. (2005) \\
\hline $\begin{array}{l}\text { Arctic, } 500 \mathrm{~km} \mathrm{~N} \text { of } \\
\text { Alaskan coast }\end{array}$ & $165^{\circ} \mathrm{W}, 76^{\circ} \mathrm{N}$ & May 1998 & 0.8 & DRI & $\begin{array}{l}\text { A; Arctic Clouds Ex- } \\
\text { periment }\end{array}$ & Yum and Hudson (2001) \\
\hline Southern Africa & $22-36.5^{\circ} \mathrm{E}, 15-30.5^{\circ} \mathrm{S}$ & $\begin{array}{l}\text { Aug-Sep 2000; Jan 1999; } \\
\text { Mar-Apr } 2001\end{array}$ & 0.3 & Wyoming STGDCC & $\begin{array}{l}\text { SAFARI-2000; } \\
\text { ARREX-1999; } \\
\text { ARREX-2001 }\end{array}$ & Ross et al. (2003) \\
\hline Off west coast of USA & $130-124^{\circ} \mathrm{W}, 38-44^{\circ} \mathrm{N}$ & Apr 2004 & $0.2-1.0$ & Wyoming STGDCC/DMT-CCNC & Sh, CIFEX & Roberts et al. (2006) \\
\hline $\begin{array}{l}\text { Mace Head, } \\
\text { Ireland }\end{array}$ & $9.9^{\circ} \mathrm{W}, 53.3^{\circ} \mathrm{N}$ & Mar 1994-Sep 1002 & 0.5 & M-1 & $\mathrm{Su}$ & Reade et al. (2006) \\
\hline $\begin{array}{l}\text { Pacific Ocean off coast } \\
\text { of California, USA }\end{array}$ & $125-120^{\circ} \mathrm{W} ; 31-34^{\circ} \mathrm{N}$ & Jun-Jul 1987 & $0.02-1.0$ & DRI & A, FIRE-1 & $\begin{array}{l}\text { Hudson and Xie (1999); Hudson } \\
\text { and Frisbie (1991b) }\end{array}$ \\
\hline $\begin{array}{l}\text { Atlantic Ocean } \\
\text { between Canaries and } \\
\text { Azores }\end{array}$ & $25-17.5^{\circ} \mathrm{W}, 27.5-37.5^{\circ} \mathrm{N}$ & Jun 1992 & $0.02-0.6$ & DRI & A, ASTEX & $\begin{array}{l}\text { Hudson and Xie (1999); Yum and } \\
\text { Hudson (2002) }\end{array}$ \\
\hline $\begin{array}{l}\text { Balbina, Amazon } \\
\text { basin }\end{array}$ & $59.4^{\circ} \mathrm{W}, 1.92^{\circ} \mathrm{S}$ & Mar-Apr 1998 & $0.15-1.5$ & STGDCC & Su, LBA-CLAIRE & Roberts et al. (2001) \\
\hline Indian Ocean & $72-74^{\circ} \mathrm{E}, 8^{\circ} \mathrm{S}-0^{\circ} \mathrm{S}$ & Feb-Mar 1999 & $0.1-1.0$ & DRI & Sh, INDOEX & Hudson and Yum (2002) \\
\hline $\begin{array}{l}\text { Southern Ocean, } \\
\text { off Cape Grim, } \\
\text { Tasmania }\end{array}$ & $144^{\circ} \mathrm{E}, 43-44^{\circ} \mathrm{N}$ & Jan-Feb 1995; Jul 1993 & $0.02-1.0$ & DRI & $\begin{array}{l}\text { SOCEX-I and SOCEX- } \\
\text { II }\end{array}$ & Yum and Hudson (2004) \\
\hline $\begin{array}{l}\text { Pacific Ocean, } \\
\text { near Hawaii }\end{array}$ & $156.9^{\circ} \mathrm{W}, 20.7^{\circ} \mathrm{N}$ & Jul-Aug 1990 & 0.8 & DRI & $\mathrm{HaRP}$ & Hudson (1993) \\
\hline $\begin{array}{l}\text { Pacific Ocean, off the } \\
\text { coast of Washington } \\
\text { State, USA }\end{array}$ & $128^{\circ} \mathrm{W}, 47^{\circ} \mathrm{N}$ & $\begin{array}{l}\text { Dec 1988, Jun 1989, Apr } \\
1990\end{array}$ & 1.0 & CCNS & A & Hegg et al. (1991) \\
\hline Reno, USA & $119.8^{\circ} \mathrm{W}, 39.5^{\circ} \mathrm{N}$ & Dec 1988-May 1990 & 0.75 & DRI & Su & Hudson and Frisbie (1991a) \\
\hline North Atlantic & $11-13^{\circ} \mathrm{W}, 32-38^{\circ} \mathrm{N}$ & Jul 1997 & $0.2-1.0$ & $\mathrm{CCN}$ spectrometer & A; ACE-2 & Johnson et al. (2000) \\
\hline Puerto Rico & $65.6^{\circ} \mathrm{W}, 18.4^{\circ} \mathrm{N}$ & 9-18 Dec 2004 & $0.5 ; 0.6$ & Mainz SDC & $\mathrm{Su}$ & Allan et al. (2008) \\
\hline
\end{tabular}

resolution of $\sim 2.8^{\circ}$ by $\sim 2.8^{\circ}$ and 31 vertical levels between the surface and $10 \mathrm{hPa}$. The version of GLOMAP used here has been used in numerous previous studies where it has been extensively evaluated against observations (Korhonen et al., 2008a, b; Merikanto et al., 2009, 2010; Meztger et al., 2010; Spracklen et al., 2008a, b, 2010).

GLOMAP simulates the sizes, number concentrations and composition of aerosols treating the particle size distribution using a two-moment sectional (bin) scheme. In our study carbonaceous combustion aerosol is defined as internally mixed particles originating from combustion sources (fossil and biofuel combustion, biomass burning) consisting of $\mathrm{BC}$ and POM. We used two externally mixed distri- butions, each described with 20 sections spanning $3 \mathrm{~nm}$ to $10 \mu \mathrm{m}$ dry diameter. One distribution, representing freshly emitted carbonaceous combustion aerosol, contains POM and $\mathrm{BC}$, is treated as initially non-hydrophilic and is not wet scavenged. The other distribution contains SU, SeaS, BC and POM, is treated as hydrophilic and is wet scavenged. We assumed that only particles in the hydrophilic distribution can act as CCN. Microphysical processes cause particles in the non-hydrophilic distribution to move into the hydrophilic distribution. Concentrations of $\mathrm{CCN}$ were calculated from the composition-resolved particle size distribution and corresponding hygroscopicity parameters as described in Sect. 3.4. The microphysical processes in the model include 
Table 1. Continued.

\begin{tabular}{|c|c|c|c|c|c|c|}
\hline Location & Latitude/Longitude & Time & $\mathrm{S}(\%)$ & $\mathrm{CCN}_{\text {Instrument }}{ }^{1}$ & $\begin{array}{l}\text { Platform }{ }^{2} \text {; Field Cam- } \\
\text { paign }\end{array}$ & Reference \\
\hline Puerto Rico & $65.7^{\circ} \mathrm{W}, 18.3^{\circ} \mathrm{N}$ & 29 Mar-9 Apr 1992 & 0.5 & M-1 & $\mathrm{Su}$ & Novakov and Penner (1993) \\
\hline $\begin{array}{l}\text { Rondonia, Amazon } \\
\text { Basin }\end{array}$ & $61.9^{\circ} \mathrm{W}, 10.9^{\circ} \mathrm{S}$ & $\begin{array}{l}\text { Jan-Mar 1999, Oct-Nov } \\
1999\end{array}$ & 1.0 & M-1 & LBA-EUSTACH & Williams et al. (2002) \\
\hline Amazon Basin & $73^{\circ} \mathrm{W},-5^{\circ} \mathrm{N} \& 63^{\circ} \mathrm{W}, 12^{\circ} \mathrm{S}$ & Oct 2002 & 1.0 & STGDCC & LBA-SMOCC & Andreae et al. (2004) \\
\hline Atlantic Ocean & $11-14^{\circ} \mathrm{W}, 33-40^{\circ} \mathrm{N}$ & Jul 1997 & 0.2 & CCNS & A; ACE-2 & Osborne et al. (2000) \\
\hline Atlantic Ocean & $11-13^{\circ} \mathrm{W}, 30-38^{\circ} \mathrm{N}$ & Jul 1997 & $0.2-1.0$ & CCN Spectrometer & A; ACE-2 & Wood et al. (2000) \\
\hline NW Korea & $126.2^{\circ} \mathrm{W}, 33.3^{\circ} \mathrm{N}$ & Mar-Apr 2005 & 0.6 & DMT-CCNC & $\mathrm{Su}$ & Yum et al. (2007) \\
\hline Nagoya, Japan & $135.9^{\circ} \mathrm{E}, 35.1^{\circ} \mathrm{N}$ & Dec 1998-Jan 1999 & 0.5 & $\mathrm{CCNC}$ & $\mathrm{Su}$ & Ishizaka and Adhikari (2003) \\
\hline $\begin{array}{l}\text { Palmer station, } \\
\text { Antarctica }\end{array}$ & $64.1^{\circ} \mathrm{W}, 64.8^{\circ} \mathrm{S}$ & Jan-Feb 1994 & $1.0 ; 0.3$ & CCNS & $\mathrm{Su}$ & Defelice et al. (1997) \\
\hline Finokalia, Greece & $25.7^{\circ} \mathrm{E}, 35.5^{\circ} \mathrm{N}$ & Jun-Oct 2007 & $0.21-0.73$ & DMT-CCNC & $\mathrm{Su}$ & Bougiatioti et al. (2009) \\
\hline $\begin{array}{l}\text { East coast of } \\
\text { Florida, USA }\end{array}$ & $80.5^{\circ} \mathrm{W}, 28.5^{\circ} \mathrm{N}$ & Jul-Aug 1995 & 1.0 & DRI & A; SCMS & Hudson and Yum (2001) \\
\hline Jeju Island, Korea & $126.1^{\circ} \mathrm{E}, 33.2^{\circ} \mathrm{N}$ & Mar-Apr 2005 & $0.09-0.97$ & DMT-CCNC & $\begin{array}{l}\text { Su, Atmospheric } \\
\text { Brown Cloud }\end{array}$ & Kuwata et al. (2008) \\
\hline $\begin{array}{l}\text { Kaashidhoo Cli- } \\
\text { mate Observatory }\end{array}$ & $73.47^{\circ} \mathrm{E}, 4.97^{\circ} \mathrm{N}$ & Feb-Mar 1999 & $0.3,0.5$ & CCNR & Su, INDOEX; & Cantrell et al. (2001) \\
\hline $\begin{array}{l}\text { Laramie, Wyoming, } \\
\text { USA }\end{array}$ & $105.6^{\circ} \mathrm{W}, 41.3^{\circ} \mathrm{N}$ & $\begin{array}{l}\text { Jun-Sep 1996; Nov 1995; } \\
\text { Jan } 1997\end{array}$ & 1.0 & STGDCC & A & Delene and Deshler (2001) \\
\hline $\begin{array}{l}\text { Lauder, New } \\
\text { Zealand }\end{array}$ & $169.7^{\circ} \mathrm{E}, 45.0^{\circ} \mathrm{S}$ & Feb 1996 & 1.0 & STGDCC & A & Delene and Deshler (2001) \\
\hline Ivory Coast, Africa & $7^{\circ} \mathrm{E}, 5^{\circ} \mathrm{N}$ & Dry \& wet season & $0.32-0.85$ & TGDCC & $\mathrm{Su}$ & Désalmand (1985) \\
\hline Tenerife, Atlantic & $16.3^{\circ} \mathrm{W}, 28.5^{\circ} \mathrm{N}$ & Jun-Jul 1997 & 1.0 & Wyoming STGDCC & $\mathrm{A} ; \mathrm{ACE}-2$ & Snider and Brenguier (2000) \\
\hline $\begin{array}{l}\text { Arctic, Near Prudhoe } \\
\text { Bay, Alaska }\end{array}$ & $70.3^{\circ} \mathrm{N}, 148.3^{\circ} \mathrm{W}$ & Jun 1995 & 1.0 & CFDCC & A & Hegg et al. (1996) \\
\hline $\begin{array}{l}\text { NW Atlantic, off } \\
\text { Nova Scotia }\end{array}$ & $43.8^{\circ} \mathrm{N}, 66.1^{\circ} \mathrm{W}$ & Aug-Sep 1993 & $0.06 ; 0.4$ & M1 (0.4\%); IHC(0.06\%) & A, NARE & Liu et al. (1996) \\
\hline $\begin{array}{l}\text { El Yunque peak, Puerto } \\
\text { Rico }\end{array}$ & $65.75^{\circ} \mathrm{W}, 18.32^{\circ} \mathrm{N}$ & Mar-Apr 1992 & 0.5 & M1 & $\mathrm{Su}$ & Rivera-Carpio et al. (1996) \\
\hline $\begin{array}{l}\text { Point Reyes, California } \\
\text { coast, USA }\end{array}$ & $122.98^{\circ} \mathrm{W}, 38^{\circ} \mathrm{N}$ & Oct 1993, Jun-Jul 1994 & 0.5 & M1 & $\mathrm{Su}$ & Rivera-Carpio et al. (1996) \\
\hline Amazon basin & $59.5^{\circ} \mathrm{W}, 1.9^{\circ} \mathrm{S}$ & Jul 2001 & $0.12-1.2$ & STGDCC & $\mathrm{Su}$ & Rissler et al. (2004) \\
\hline $\begin{array}{l}\text { Oregon Coast, } \\
\text { USA }\end{array}$ & $124.1^{\circ} \mathrm{W}, 44.6^{\circ} \mathrm{N}$ & Jan and Jul 1971 & $0.1-1.0$ & TGDCC & Sh & Elliot and Egami (1975) \\
\hline $\begin{array}{l}\text { Southern Ocean, } \\
\text { near Tasmania }\end{array}$ & $137^{\circ}-160^{\circ} \mathrm{E}, 40^{\circ}-55^{\circ} \mathrm{S}$ & Nov-Dec 1995 & $0.02-1.0$ & DRI & A, ACE-1 & Hudson et al. (1998) \\
\hline $\begin{array}{l}\text { Arctic Ocean, near } \\
\text { Deadhorse, Alaska }\end{array}$ & $148.5^{\circ} \mathrm{W}, 70.2^{\circ} \mathrm{N}$ & Apr 1992 & 1.0 & CCNS & A, DEADEX & Hegg et al. (1995) \\
\hline $\begin{array}{l}\text { Amazon Basin, } \\
\text { near Manaus, } \\
\text { Brazil }\end{array}$ & $60.21^{\circ} \mathrm{W}, 2.59^{\circ} \mathrm{S}$ & Feb-Mar 2008 & $0.1-0.82$ & DMT-CCNC & Su; AMAZE & Gunthe et al. (2009) \\
\hline $\begin{array}{l}\text { Fallon, Nevada, } \\
\text { USA }\end{array}$ & $118.78^{\circ} \mathrm{W}, 39.47^{\circ} \mathrm{N}$ & Aug-Oct 1975 & 0.91 & CFDCC & $\mathrm{Su}$ & Hudson and Squires (1978) \\
\hline
\end{tabular}

nucleation, coagulation, condensation of gas-phase species, in-cloud and below-cloud aerosol scavenging and deposition, dry deposition and cloud processing.

Concentrations of the oxidants $\mathrm{OH}, \mathrm{O}_{3}, \mathrm{H}_{2} \mathrm{O}_{2}, \mathrm{NO}_{3}$ and $\mathrm{HO}_{2}$ were specified using 6-hourly monthly mean 3-D concentrations from a TOMCAT simulation with detailed tropospheric chemistry (Arnold et al., 2005). Concentrations of $\mathrm{H}_{2} \mathrm{O}_{2}$ are depleted through the aqueous phase reaction with $\mathrm{SO}_{2}$ and replenished through a reaction between $\mathrm{HO}_{2}$ and $\mathrm{HO}_{2}$ as described in Spracklen et al. (2005).

Oceanic DMS emissions were calculated using the ocean surface DMS concentration database of Kettle and An- dreae (2000) and the sea-to-air transfer velocity according to Nightingale et al. (2000). Emissions of biogenic terpenes are from the Global Emissions Inventory Activity (GEIA) inventory and are based on Guenther et al. (1995). Emissions of sea salt were calculated using the scheme of Gong (2003). Emissions of $\mathrm{SO}_{2}$ and carbonaceous combustion aerosol from wildfires, biofuel, fossil fuel and volcanoes are based on the Aerosol Intercomparison Project (AeroCom) emission inventories for the year 2000 (Dentener et al., 2006). This inventory bases carbonaceous combustion aerosol emissions from wildfire on the Global Fire Emission Database (GFED) inventory (van der Werf et al., 2004) 
Table 1. Continued.

\begin{tabular}{lllllll}
\hline Location & Latitude/Longitude & Time & S $(\%)$ & CCN Instrument ${ }^{1}$ & $\begin{array}{l}\text { Platform }{ }^{2} ; \text { Field Cam- } \\
\text { paign }\end{array}$ \\
\hline $\begin{array}{l}\text { Cheeka Peak, } \\
\begin{array}{l}\text { Washington State } \\
\text { USA }\end{array}\end{array}$ & $124.62^{\circ} \mathrm{W}, 48.3^{\circ} \mathrm{N}$ & Apr 1991 & 0.3 & STGDCC & Su & Quinn et al. (1993) \\
\hline NE Atlantic Ocean & $27.1^{\circ} \mathrm{W}, 38.8^{\circ} \mathrm{N}$ & Jun 1992 & & & \\
\hline $\begin{array}{l}\text { Fazenda Nossa, } \\
\text { Amazon basin }\end{array}$ & $62.35^{\circ} \mathrm{W}, 10.8^{\circ} \mathrm{S}$ & Oct to Nov 2002 & $0.2-1.12$ & TGDCC & Su, LBA-SMOCC & Vestin et al. (2007) \\
\hline Guangzhou, China & $113.1^{\circ} \mathrm{E}, 23.54^{\circ} \mathrm{N}$ & $1-30$ Jul 2006 & $0.07-1.27$ & DMT-CCNC & Su & Rose et al. (2010) \\
\hline
\end{tabular}

1 DRI: Desert Research Institute (DRI) airborne instantaneous CCN spectrometer (Hudson, 1989); CCN spectrometer (Hoppel et al., 1979; Saxena and Kassner, 1970; Fukuta and Saxena, 1979a, b; Radke at al., 1981); DMT-CCNC: Droplet measurement technologies (DMT) stream-wise thermal-gradient CCN counter (Roberts and Nenes, 2005; Lance et al., 2006; Rose et al., 2008); CCNR: CCN Remover (Ji et al., 1998); TGDCC: Thermal-gradient diffusion cloud chamber (Désalmand, 1985); STGDCC: Static thermal-gradient diffusion cloud chamber (Delene et al., 1998; Delene and Deshler, 2000); IHC: Isothermal Haze Counter (Fitzgerald et al., 1981); M-1: DH Associates, parallel-plate diffusion cloud chamber (Phillipin and Betterton, 1997); SDC: Static parallel-plate thermal-gradient diffusion cloud chamber (Frank et al., 2007); CFDCC: Continuous-flow diffusion cloud chamber (Hudson and Squires, 1976; Hudson and Alofs, 1981); CCNC: CCN counter (Model 130, Mee) (Ishizaka et al., 2003). 2 Su: surface; Sh: ship; A: above the surface (aircraft or balloon).

Table 2. Annual global emission flux of black carbon (BC) and particulate organic matter (POM) for wildfire, biofuel and fossil fuel emissions. The numbers in parentheses indicate the percentage of total emission.

\begin{tabular}{lrrr}
\hline \multirow{3}{*}{ Source } & \multicolumn{3}{c}{ Flux $\left(\mathrm{Tg} \mathrm{a}^{-1}\right)$} \\
\cline { 2 - 4 } & $\mathrm{BC}$ & $\mathrm{POM}$ & $\mathrm{BC}+\mathrm{POM}$ \\
\hline Wildfire & $3.0(39.5 \%)$ & $34.7(73.8 \%)$ & $37.7(69.0 \%)$ \\
Biofuel & $1.6(21.0 \%)$ & $9.1(19.4) \%$ & $10.7(19.6 \%)$ \\
Fossil fuel & $3.0(39.5 \%)$ & $3.2(6.8 \%)$ & $6.2(11.3 \%)$ \\
TOTAL & 7.6 & 47 & 54.6 \\
\hline
\end{tabular}

and carbonaceous combustion aerosol emissions from fossil fuel and biofuel burning on the Speciated Particulate Emissions Wizard (SPEW) inventory (Bond et al., 2004). Table 2 details the emission fluxes for carbonaceous combustion aerosol sources from this emission inventory.

Secondary organic aerosol (SOA) from biogenic terpenes is included assuming the reactivity of alpha-pinene including reactions with $\mathrm{OH}, \mathrm{O}_{3}$ and $\mathrm{NO}_{3}$ (Spracklen et al., 2006). We assumed all three reactions have a constant molar yield of $13 \%$ to a first-stage oxidation product that condenses with zero vapour pressure onto existing aerosol (Spracklen et al., 2006,2008 a). We added SOA to the hydrophilic aerosol distribution. All experiments included SOA.

The model has been extensively evaluated against observations in previous work. GLOMAP reproduces observed total particle number (Spracklen et al., 2010) and particle size distribution in both continental (Spracklen et al., 2008a) and marine regions (Spracklen et al., 2007). We have previously shown that GLOMAP reproduces realistic CCN concentrations at a limited number of locations (Spracklen et al., 2008a; Korhonen et al., 2008a). In this work we evaluate GLOMAP against the extensive global CCN dataset described in Sect. 2.

\subsection{Model experiments}

Table 3 details the 9 model simulations that we used in this analysis. The first set of simulations (simulations 1-7) was used to evaluate the contribution of carbonaceous combustion aerosol to present day CCN. In all these simulations we included emissions of carbonaceous combustion aerosol. In simulations 1 and 2 we changed model assumptions that determine whether carbonaceous combustion aerosol can act as CCN. In simulations 3-7 we evaluated the sensitivity of the results to primary particle emissions, rates of new particle formation, and the rate of ageing of the carbonaceous combustion aerosol. In a second set of simulations (simulations 8 and 9) we removed carbonaceous combustion aerosol emissions (in simulation 8 we removed all carbonaceous combustion aerosol emissions and in simulation 9 we removed only pollution (fossil fuel and biofuel) carbonaceous combustion aerosol emissions). We used simulations 8 and 9 along with the simulation including carbonaceous combustion aerosol (simulation 2) to calculate the aerosol radiative effect that would occur due to reductions in carbonaceous combustion aerosol emissions.

In all simulations non-hydrophilic particles can coagulate with hydrophilic particles and thereby add mass to the hydrophilic (CCN-active) particle distribution. In no_age (simulation 1) this is the only process that moves non-hydrophilic carbonaceous combustion aerosol into the hydrophilic distribution, but does not affect the number concentration of hydrophilic particles. This process is relatively slow, resulting in a carbonaceous combustion aerosol lifetime in the nonhydrophilic distribution of 3.3 days and $75 \%$ of the carbonaceous combustion aerosol mass exists in the non-hydrophilic distribution. In all the other simulations the non-hydrophilic particles are also assumed to age chemically through condensation of soluble gas-phase species. We assume that particles move from the non-hydrophilic to hydrophilic distribution when they have been coated with one monolayer of watersoluble condensed material (in our model, sulfuric acid and secondary organic aerosol material). This process rapidly 
Table 3. Details of GLOMAP model simulations.

\begin{tabular}{|c|c|c|c|c|c|c|c|c|}
\hline \multirow[t]{2}{*}{ \# } & \multirow[b]{2}{*}{$\begin{array}{l}\text { Experiment } \\
\text { name }\end{array}$} & \multicolumn{2}{|c|}{$\begin{array}{l}\text { Carbonaceous combustion } \\
\text { aerosol (CCA) emissions }\end{array}$} & \multirow[b]{2}{*}{$\begin{array}{l}\text { Condensation } \\
\text { ageing }^{1}\end{array}$} & \multirow[b]{2}{*}{$\begin{array}{c}\# \\
\text { monolayers }^{2}\end{array}$} & \multirow[b]{2}{*}{$\begin{array}{c}\text { Particle } \\
\text { formation }^{3}\end{array}$} & \multicolumn{2}{|c|}{$\begin{array}{c}\text { Primary emissions } \\
\text { scheme }\end{array}$} \\
\hline & & $\begin{array}{l}\text { Fossil Fuel/ } \\
\text { Biofuel }\end{array}$ & Wildfire & & & & $\mathrm{CCA}^{4}$ & Sulf. ${ }^{5}$ \\
\hline 1 & no_age & Yes & Yes & No & N/A & BHN & $S$ & A \\
\hline 2 & $\mathrm{CCA}$ & Yes & Yes & Yes & 1 & BHN & S & A \\
\hline 3 & bln1 & Yes & Yes & Yes & 1 & $\mathrm{BHN}+\mathrm{BLN}\left(A=2 \times 10^{-6} \mathrm{~s}^{-1}\right)$ & S & A \\
\hline 4 & $b \ln 2$ & Yes & Yes & Yes & 1 & $\mathrm{BHN}+\mathrm{BLN}\left(A=2 \times 10^{-5} \mathrm{~s}^{-1}\right)$ & $S$ & A \\
\hline 5 & small_CCA & Yes & Yes & Yes & 1 & BHN & $\mathrm{A}$ & $\mathrm{A}$ \\
\hline 6 & small_sul & Yes & Yes & Yes & 1 & BHN & $S$ & $\mathrm{~S}$ \\
\hline 7 & slow_age & Yes & Yes & Yes & 5 & BHN & S & A \\
\hline 8 & no_CCA & No & No & Yes & 1 & BHN & N/A & A \\
\hline 9 & no_ff_bf_CCA & No & Yes & Yes & 1 & $\mathrm{BHN}$ & $\mathrm{S}$ & A \\
\hline
\end{tabular}

${ }^{1}$ Whether carbonaceous combustion aerosol ages through condensation of soluble gas-phase species from the hydrophobic to hydrophilic distributions. Carbonaceous combustion aerosol in the hydrophilic distribution can act as $\mathrm{CCN}$.

2 Number of monolayers of condensable gas-phase species required to age carbonaceous combustion aerosol.

${ }^{3}$ Binary homogeneous nucleation of $\mathrm{H}_{2} \mathrm{SO}_{4}-\mathrm{H}_{2} \mathrm{O}(\mathrm{BHN})$, Boundary layer nucleation (BLN). For BLN the nucleation rate constant $(A)$ is given.

${ }^{4}$ Assumed size distribution of carbonaceous combustion aerosol emissions: S: Stier et al. (2005): Fossil fuel emissions number mean radius $(r)=30$ nm, $\sigma=1.8$; wildfire and biofuel emissions: $r=75 \mathrm{~nm}, \sigma=1.59$. A: AeroCom: Fossil fuel emissions: $r=15 \mathrm{~nm}, \sigma=1.8$; wildfire and biofuel emissions: $r=40 \mathrm{~nm}, \sigma=1.8$.

5 Assumed size distribution of primary sulfate emissions: A: road transport: $r=15 \mathrm{~nm}, \sigma=1.8$; shipping, industry and power-plant emissions: $r=500 \mathrm{~nm}, \sigma=1.8$; volcanic emissions: $50 \%$ at $r=15 \mathrm{~nm}$ and $50 \%$ at $r=40 \mathrm{~nm}, \sigma=1.8$. S: Adams and Seinfeld (2002): $15 \%$ at $r=5 \mathrm{~nm}, \sigma=1.6 ; 85 \%$ at $r=35 \mathrm{~nm}, \sigma=2.0$.

moves carbonaceous combustion aerosol to the hydrophilic distribution and results in a lifetime in the non-hydrophilic distribution of 0.1 days. In these simulation $93 \%$ of the carbonaceous combustion aerosol mass is found in the hydrophilic distribution where it can act as CCN. The model is relatively insensitive to our assumption of the amount of condensable material that is required to age carbonaceous combustion aerosol. Increasing the amount from 1 to 5 monolayers (simulation 7, slow_age) increases the lifetime with respect to ageing to 0.3 days and reduces the amount of carbonaceous combustion aerosol in the hydrophilic distribution to $90 \%$.

We tested the sensitivity of simulated $\mathrm{CCN}$ number concentrations to uncertainty in new particle formation (nucleation). All model simulations include particle formation assuming binary homogeneous $\mathrm{H}_{2} \mathrm{SO}_{4}-\mathrm{H}_{2} \mathrm{O}$ nucleation using the parameterisation of Kulmala et al. (1998). In simulations 3 and 4 (bln1 and bln2) we included an additional boundary layer nucleation (BLN) mechanism where the formation rate of 1-nm clusters $\left(J_{1}\right)$ was proportional to the gas-phase sulfuric acid concentration $\left(\left[\mathrm{H}_{2} \mathrm{SO}_{4}\right]\right)$ to the power of one (Sihto et al., 2006; Kulmala et al., 2006):

$J_{1}=k\left[\mathrm{H}_{2} \mathrm{SO}_{4}\right]$.

Implementation of this mechanism in the model is described in detail in Spracklen et al. $(2006,2008 \mathrm{a})$. We tested a range of nucleation rate coefficients $(k)$ from $2 \times 10^{-6}$ (bln1) to $2 \times 10^{-5} \mathrm{~s}^{-1}(\mathrm{bln} 2)$.

In all simulations we assumed that $2.5 \%$ of sulfur dioxide $\left(\mathrm{SO}_{2}\right)$ emissions are emitted as primary sulfate particles (that is sulfur that is emitted directly as a particle or undergoes gasto-particle conversion very rapidly after emission, at spatial scales much smaller than the model grid).

Our standard primary particle emission scheme assumes the size distribution for carbonaceous combustion aerosol emissions as suggested by Stier et al. (2005) and the size distribution for primary sulfate suggested by AeroCom (Dentener et al., 2006). We explored the uncertainty in the size distribution of emission through a range of model experiments that spanned the likely uncertainty in primary particulate emissions (simulations 5-6). In the simulation small_CCA we emitted carbonaceous combustion aerosol at the smaller particle sizes suggested by AeroCom. In the simulation small_sul we emitted primary sulfate at the smaller sizes suggested by Adams and Seinfeld (2002). These sensitivity tests provide a reasonable estimate of the upper limit of the contribution to the number of $\mathrm{CCN}$ from the different primary sources. Details of the emission sizes used by these schemes are included in Table 3. In Spracklen et al. (2010) we tested these different schemes against total particle number concentrations observed at 36 surface sites. We showed that the upper limit for primary sulfate number concentrations (small_sul) is unlikely as it results in overprediction of total particle number at many surface locations.

Table 4 records the atmospheric burden of $\mathrm{BC}$ and primary POM (i.e. not including contribution from SOA) calculated by GLOMAP for all the simulations. When carbonaceous combustion aerosol emissions are included and are assumed to age rapidly through condensation of soluble gases (simulations 2-6) the $\mathrm{BC}$ burden is $0.09 \mathrm{Tg}\left(0.18 \mathrm{mg} \mathrm{m}^{-2}\right)$ and 
Table 4. Global mass budgets of black carbon (BC) and primary particulate organic matter (POM), mean CCN calculated at same locations and supersaturations $(S)$ as the CCN observations listed in Table 1, normalised mean bias (NMB) between model and observations, annual mean surface $\mathrm{CCN}(S=0.2 \%)$ for oceanic and continental regions and annual global mean cloud droplet number concentration (CDNC, calculated for an updraft velocity of $\left.0.4 \mathrm{~m} \mathrm{~s}^{-1}\right)$ in low level clouds $(800-950 \mathrm{hPa})$ for the model simulations described in Table 3 .

\begin{tabular}{llrrrrrrr}
\hline $\begin{array}{l}\text { Experiment } \\
\text { name }\end{array}$ & \multicolumn{2}{c}{$\begin{array}{c}\text { Burden } \\
\text { BC/Tg }\end{array}$} & $\begin{array}{r}\text { Mean CCN at } \\
\text { POMservation }\end{array}$ & \multicolumn{2}{c}{ NMB/\% } \\
locations/cm
\end{tabular}

a $\mathrm{NMB}=100 \% \times \Sigma\left(S_{i}-O_{i}\right) / \Sigma O_{i}$ where $S_{i}$ is simulated concentration and $O_{i}$ is observed concentration. Values in round brackets are calculated when we limit our analysis to CCN observations made over the period 1995-2010. Values in square brackets are when we limit our analysis to CCN observations that represent a sampling period $>10$ days. We do not calculate this model-observation comparison for the two mitigation experiments (simulations 8 and 9).

the POM burden is $0.55 \mathrm{Tg}\left(1.10 \mathrm{mg} \mathrm{m}^{-2}\right)$. These burdens lie within the range calculated by the AeroCom simulations: multi-model mean burden for $\mathrm{BC}$ is $0.125 \mathrm{Tg}$, range 0.08 $0.19 \mathrm{Tg}$ whilst for POM it is $0.66 \mathrm{Tg}$, range $0.44-0.92 \mathrm{Tg}$ (Forster et al., 2007). When we did not allow carbonaceous combustion aerosol to age from the hydrophobic to the hydrophilic distribution through the condensation of soluble gas-phase species (simulation no_age), the particles are protected from wet deposition, and the atmospheric burden is increased (BC burden of $0.12 \mathrm{Tg}$; POM burden of $0.73 \mathrm{Tg}$ ). When we removed all carbonaceous combustion aerosol emissions, the primary POM and BC burdens were zero. When we removed only pollution carbonaceous combustion aerosol emissions, the $\mathrm{BC}$ burden was $0.04 \mathrm{Tg}$ and the POM burden was $0.36 \mathrm{Tg}$.

\subsection{Evaluation against IMPROVE observations}

We evaluated the ability of GLOMAP to simulate carbonaceous combustion aerosol using observed BC mass concentrations from the Interagency Monitoring of Protected Visual Environments (IMPROVE) network (Malm et al., 1994). We did not use organic aerosol observations from IMPROVE as they include contributions both from carbonaceous combustion emissions and from SOA which complicates any analysis. IMPROVE observations are from rural and background locations which were recently shown to be the most appropriate for testing the ability of global models, with relatively coarse spatial resolution, to simulate $\mathrm{BC}$ aerosol mass (Koch at el., 2009). We used observed monthly mean IMPROVE concentrations for the year 2000 which is the year simulated by the model. Simulation of BC by GLOMAP $\left(\mathrm{NMB}=-39 \%, r^{2}=0.49\right)$ is within the range of model skill
$(\mathrm{NMB}=-71 \%$ to $+670 \%)$ recorded by the recent AeroCom model intercomparison (Koch et al., 2009).

\subsection{Calculation of $\mathrm{CCN}$ concentrations}

We calculated CCN concentrations using the simulated aerosol size distribution and a hygroscopicity parameter $(\kappa)$ from Petters and Kreidenweis (2007). $\kappa$ represents a quantitative measure of aerosol water uptake and $\mathrm{CCN}$ activity due to chemical composition of the aerosol particle. We assumed the following values of $\kappa$ for the different aerosol components: sulfate (0.61), sea-salt (1.28), BC (0.0) and POM (0.227). Our model does not include dust or nitrate. However, we have previously shown that dust has relatively little impact on $\mathrm{CCN}$, reducing $\mathrm{CCN}$ concentrations by up to $10 \%$ locally (Manktelow et al., 2010). The value of $\kappa$ for organic material is uncertain, but is likely to lie within the range 0.009 to 0.4 (Petters and Kreidenweis, 2007). Changing the assumed value of $\kappa$ for POM over this uncertainty range changed the mean $\mathrm{CCN}$ calculated at the observation locations by only $4 \%$. Table 4 shows global mean surface concentrations of $\mathrm{CCN}$ calculated from the different model simulations.

For comparison with the observations we linearly interpolated the model to the horizontal location of the observations. All the CCN observations are in the boundary layer (BL) with the majority at the surface. We used $\mathrm{CCN}$ values from the model surface layer (TOMCAT uses hybrid $\sigma$-pressure coordinates). We calculated model $\mathrm{CCN}$ at the same supersaturation as the observations and compared the model for the same calendar month as the observations using simulations for the year 2000. Due to the relatively long-term nature of the observations (typically 5 days to weeks in length), 
meteorological variability between the years of observation and the simulation year (2000) are not likely to be a significant problem in these comparisons.

\section{Results}

\subsection{Comparison of observed and simulation CCN concentrations}

To quantify the contribution of carbonaceous combustion aerosol to CCN we compared two simulations: both included carbonaceous combustion aerosol emissions but in one simulation carbonaceous combustion aerosol particles are able to act as $\mathrm{CCN}$ (CCA, simulation 1) whereas in the other they are not (no_age, simulation 2). This approach allows us to quantify the fraction of $\mathrm{CCN}$ that are present in today's atmosphere due to the emission of carbonaceous combustion aerosol. Figure $1 \mathrm{~b}$ and $\mathrm{c}$ show simulated surface concentrations of $\mathrm{CCN}$ under these two scenarios. Assuming that the carbonaceous combustion aerosol does not act as CCN, modelled CCN concentrations do not exceed $\sim 1000 \mathrm{~cm}^{-3}$ even in polluted regions. When carbonaceous combustion aerosol act as CCN, simulated CCN concentrations over polluted regions of Europe, United States and Asia are as great as $\sim 10000 \mathrm{~cm}^{-3}$.

Figure 2 compares observed and simulated $\mathrm{CCN}$ concentrations and Table 4 reports the normalised mean bias (NMB) between model and observations. When carbonaceous combustion aerosol does not act as $\mathrm{CCN}$ the model is biased low $(\mathrm{NMB}=-77 \%)$. Allowing carbonaceous combustion aerosol to act as $\mathrm{CCN}$ results in a better agreement with observations ( $\mathrm{NMB}=-25 \%)$. We used the Wilcoxon signedrank test (an alternative to the paired t-test used when the population cannot be assumed to be normally distributed) to assess whether the means of the simulated and observed populations differ. The model simulation where carbonaceous combustion aerosol does not act as CCN is significantly different from the observations $(\mathrm{P} \ll 0.0001)$. When carbonaceous combustion aerosol acts as CCN the difference between simulated and observed CCN is statistically insignificant $(\mathrm{P}=0.38)$.

Another metric of model performance is the ratio of simulated to observed CCN concentrations. Figure 3 shows this ratio as a probability density function for the model simulation when we allow carbonaceous combustion aerosol to act as CCN and for the model simulation when we do not. We fit a Gaussian to each probability density function. We use simulated concentrations of $\mathrm{BC}$ aerosol to define clean $\left(\mathrm{BC}<50 \mathrm{ng} \mathrm{m}^{-3}\right)$ and polluted $\left(\mathrm{BC}>100 \mathrm{ng} \mathrm{m}^{-3}\right)$ conditions in line with previous studies (Yoon et al., 2007). In clean conditions (Fig. 3a) the simulated to observed CCN ratio is not strongly biased in either simulation. This suggests that there is not a strong bias in our representation of natural $\mathrm{CCN}$ sources. In polluted conditions (Fig. 3b) the model is biased low (center of fitted Gaussian at a model to observed ratio of 0.26) when we do not allow carbonaceous combustion aerosol act as CCN. The model bias is greatly reduced when we allow carbonaceous combustion aerosol to act as CCN (center of fitted Gaussian at model to observed ratio of 0.98).

A deeper analysis of the $\mathrm{CCN}$ observations confirms the contribution of carbonaceous combustion aerosol to CCN. We binned the observed and modelled CCN concentrations into remote and polluted locations and further into four supersaturation categories covering the measured range from $0.02 \%$ to $1.5 \%$. As before we used simulated concentrations of BC aerosol to define clean (Fig. $2 \mathrm{c}, \mathrm{BC}<50 \mathrm{ng} \mathrm{m}^{-3}$ ) and polluted (Fig. 2d, BC $>100 \mathrm{ng} \mathrm{m}^{-3}$ ) conditions. Measurements at low supersaturation, which are most relevant to atmospheric conditions, include the larger particles in the size distribution whereas high supersaturations additionally include the smaller particles. Carbonaceous combustion aerosol contributes to $\mathrm{CCN}$ across the range of atmospherically relevant cloud supersaturations and in both remote and polluted environments. In polluted locations the model is biased low unless carbonaceous combustion aerosol acts as $\mathrm{CCN}$. We explored the potential for other mechanisms (including primary sulfate and boundary layer nucleation) to explain observed CCN concentrations. We find that these mechanisms can make a substantial contribution to $\mathrm{CCN}$ concentrations in remote locations but are unable to explain observed $\mathrm{CCN}$ in polluted locations without a substantial contribution from carbonaceous combustion aerosol.

The uncertainty in the emitted size distribution of carbonaceous combustion aerosol leads to a broad range of simulated $\mathrm{CCN}$ concentrations ( $\mathrm{NMB}=-25 \%$ to $+37 \%$ ) spanning the observations at high supersaturation, but contributes little to the uncertainty at low supersaturations. Small primary sulfate particles, which are emitted in similar geographic regions to carbonaceous combustion aerosol, can contribute substantially to $\mathrm{CCN}$ at high supersaturations if we assume a lower limit for the size of the particles. However, this scenario is unlikely as it has been shown to overestimate total particle number concentrations (Pierce et al., 2007; Spracklen et al., 2010). Nucleation of new particles in the boundary layer (BL) reduced model bias and increases CCN concentrations by between $22 \%(\mathrm{NMB}=-9 \%)$ and $29 \%$ $(\mathrm{NMB}=-3 \%)$ depending on the nucleation rate used. However this mechanism alone is insufficient to match observed $\mathrm{CCN}$ concentrations without a substantial contribution from carbonaceous combustion aerosol. The contribution of BL particle formation calculated here is similar to previous estimates (Spracklen et al., 2008a; Merikanto et al., 2009; Pierce and Adams, 2009; Wang and Penner, 2009) and is most important at the highest supersaturations and in clean environments. The calculated CCN concentration is relatively insensitive to our assumption about the amount of soluble material required to age non-hydrophilic particles. Assuming a factor 5 slower rate of condensational ageing (slow_age) decreased 
(a)

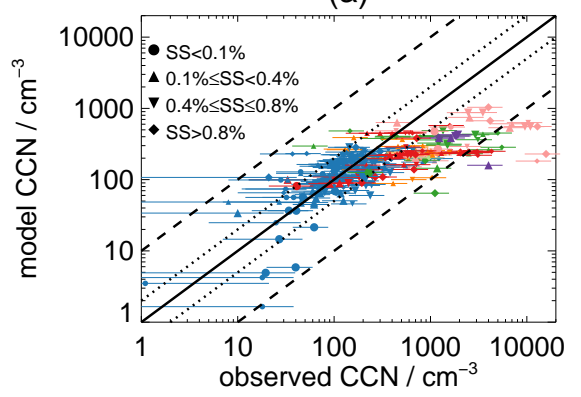

(c)

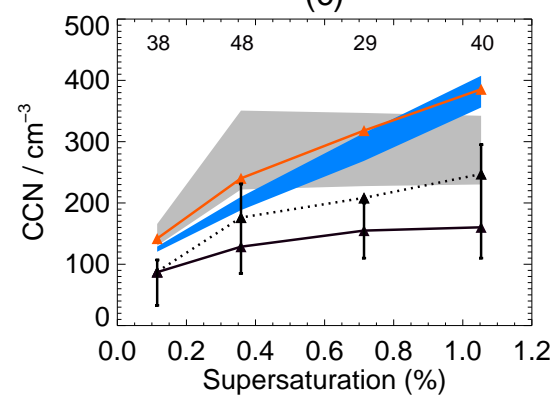

(b)

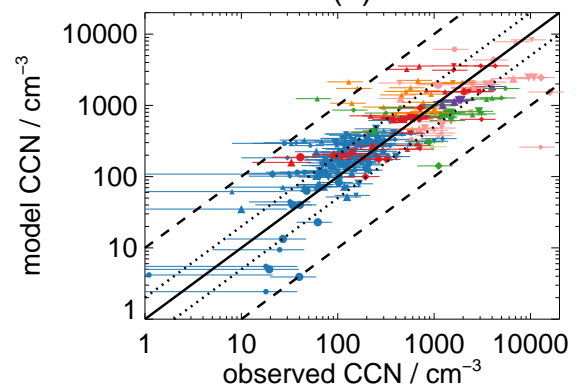

(d)

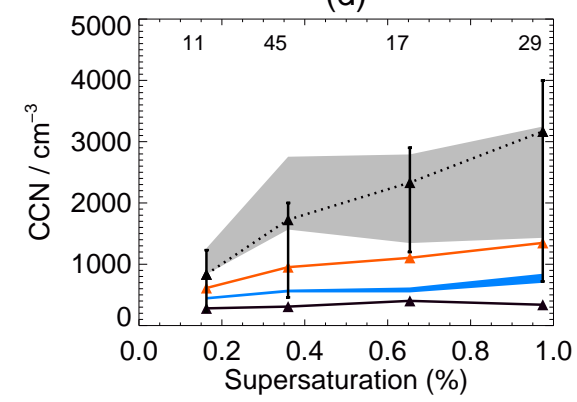

Fig. 2. Observed and simulated CCN. Simulations are (a) without, (b) with carbonaceous combustion aerosol acting as CCN. Observations (10-31 days sampling: large symbol, $<10$ days: small symbol; error in observations represented by error bars, see text) with colour indicating location (colour scale matches Fig. 1a). Solid line is the 1:1 relationship, dotted lines are the 2:1 and 1:2 relationships, dashed lines are the $10: 1$ and 1:10 relationships. Lower panels show CCN binned by supersaturation $(S)(0.02 \leq S / \%<0.15 ; 0.15 \leq S / \%<0.3 ; 0.3 \leq S / \%$ $<0.6,0.6 \leq S / \%<1.6$, with number of observations per bin shown in panel) for (c) clean (simulated BC $<50 \mathrm{ng} \mathrm{m}^{-3}$ ), (d) polluted (BC $>100 \mathrm{ng} \mathrm{m}^{-3}$ ) conditions. Observations (mean: dotted line; 25th to 75th percentiles: error bars) and simulations (without carbonaceous combustion aerosol acting as CCN: black line; as above but including BL nucleation: blue shading shows uncertainty due to nucleation rate; as above but with maximum likely contribution of primary sulfate: red line; with carbonaceous combustion aerosol acting as CCN: grey shading due to uncertainty in emitted particle size). Model values are calculated from the simulations described in Table 3.

(a)

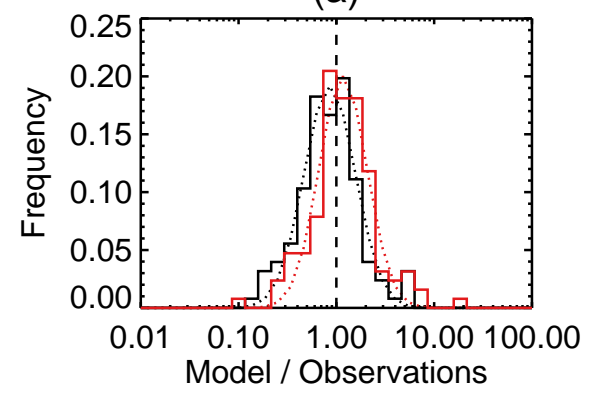

(b)

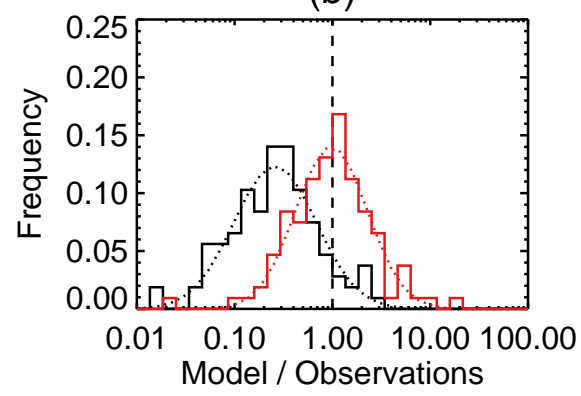

Fig. 3. Probability density functions of model to observed ratios of $\mathrm{CCN}$ concentration when carbonaceous combustion aerosol does not act as $\mathrm{CCN}$ (black line) and when carbonaceous aerosol does act as $\mathrm{CCN}$ (red line) for (a) clean conditions $\left(\right.$ simulated $\left.\mathrm{BC}<50 \mathrm{ng} \mathrm{m}^{-3}\right)$, $(\mathbf{b})$ polluted conditions $\left(\mathrm{BC}>100 \mathrm{ng} \mathrm{m}^{-3}\right)$. Dashed line indicates the model to observed ratio of 1 . The dotted lines show Gaussian fits to the probability density function.

mean CCN simulated across the observations by only $8 \%$. However, the mechanism and rate by which carbonaceous combustion aerosol become $\mathrm{CCN}$ active needs to be explored in future work.

\subsection{Contribution of carbonaceous combustion aerosol to global $\mathbf{C C N}$}

Our model simulations suggest that carbonaceous combustion aerosol contributes 52-64\% to simulated global mean surface level CCN concentrations (at $0.2 \%$ supersaturation 
typical of stratocumulus clouds), with a greater contribution of $67-75 \%$ over land compared to $34-50 \%$ over oceans (Table 4, with the upper and lower estimates due to uncertainty in size distribution of emitted carbonaceous combustion aerosol). Over the most polluted continental regions carbonaceous combustion aerosol contributes up to $80 \%$ of CCN. This large contribution of anthropogenic primary emissions to simulated $\mathrm{CCN}$ is in agreement with previous model estimates (Pierce et al., 2007; Merikanto et al., 2009), but has never previously been tested against a dataset of observed CCN.

\subsection{The radiative effect of carbonaceous combustion aerosol}

We then used the evaluated model to calculate the top-ofatmosphere direct and indirect radiative effect of eliminating carbonaceous combustion aerosol emissions. The aerosol direct effect (ADE) and cloud-albedo AIE were calculated by comparing the model simulation which included carbonaceous combustion aerosol emissions (simulation 2) to simulations where carbonaceous combustion aerosol emissions had been removed (simulations 8 and 9). In simulation 8 we removed all carbonaceous combustion aerosol emissions (no_CCA). In simulation 9 we removed only pollution (fossil fuel and biofuel) carbonaceous combustion aerosol emissions (no_ff_bf_CCA). These additional model experiments are needed to calculate the aerosol radiative effect because aerosol microphysics responds to the removal of carbonaceous combustion aerosol creating a non-linear response of aerosol concentrations to emission reductions, as we describe below. We do not calculate the cloud lifetime (second indirect) effect or semi-direct effects and so we are unable to estimate the full climate impact of carbonaceous combustion aerosol.

\subsubsection{Aerosol direct effect}

We estimated the ADE of carbonaceous combustion aerosol using the GLOMAP simulated aerosol burden together with the AeroCom multi-model mean burden and Aerocom multimodel mean ADE (Forster et al., 2007; Schultz et al., 2006). This simple method of calculating the ADE gives an order of magnitude estimate. For BC the AeroCom mean burden is $0.125 \mathrm{Tg}$ and the AeroCom mean $\mathrm{ADE}$ is $+0.25 \mathrm{~W} \mathrm{~m}^{-2}$ resulting in a radiative perturbation per unit atmospheric mass for $\mathrm{BC}$ of $2.0 \mathrm{~W} \mathrm{~m}^{-2} \mathrm{Tg}^{-1}$. For POM the AeroCom mean burden is $0.66 \mathrm{Tg}$ and the AeroCom mean ADE is $-0.13 \mathrm{~W} \mathrm{~m}^{-2}$ resulting in a radiative perturbation per unit atmospheric mass for POM of $-0.197 \mathrm{~W} \mathrm{~m}^{-2} \mathrm{Tg}^{-1}$. In GLOMAP the BC burden is $0.08 \mathrm{Tg}$ (Table 4) resulting in a ADE of $+0.16 \mathrm{~W} \mathrm{~m}^{-2}$. The POM burden in GLOMAP is $0.55 \mathrm{Tg}$ resulting in a ADE of $-0.11 \mathrm{~W} \mathrm{~m}^{-2}$.

The ADE calculated above and those from AeroCom include all carbonaceous combustion aerosol (fossil fuel, bio- fuel and wildfire). For only fossil fuel carbonaceous combustion aerosol emissions, the ADE from the AeroCom simulations is $+0.12 \mathrm{~W} \mathrm{~m}^{-2}$ due to $\mathrm{BC}$ and $-0.03 \mathrm{Wm}^{-2}$ due to POM. That is for fossil fuel carbonaceous combustion aerosol emissions, BC dominates the ADE (by a factor of 4). We find the same in the GLOMAP simulations. Pollution carbonaceous combustion aerosol (fossil fuel and biofuel emissions) results in an $\mathrm{ADE}$ of $+0.08 \mathrm{Wm}^{-2}$ due to $\mathrm{BC}$ and $-0.03 \mathrm{Wm}^{-2}$ due to POM.

\subsubsection{Aerosol indirect effect}

The AIE is the mechanism by which aerosol alters cloud properties (Forster et al., 2007). Here we calculate cloudalbedo AIE which is the change in cloud albedo due to changes in aerosol. This has also been referred to as the first AIE (e.g., Ramaswamy et al., 2001) and the cloud-albedo effect (e.g., Lohmann and Feichter, 2005).

First we calculated cloud droplet number concentrations (CDNC) using the mechanistic parameterisation of cloud drop formation (Nenes and Seinfeld, 2003) as described by Pringle et al. (2009). We have shown previously that GLOMAP reproduces realistic CDNC (Merikanto et al., 2010) and Pringle et al. (2009) showed that the model can capture observed relationships between particle number and CDNC.

We calculated CDNCs for a range of atmospherically relevant in-cloud updraft velocities $\left(0.1\right.$ to $\left.0.5 \mathrm{~m} \mathrm{~s}^{-1}\right)$ and hence realistic supersaturations. Figure 4 shows the global distribution of simulated CDNCs and Table 4 shows global annual mean CDNC (at $0.4 \mathrm{~m} \mathrm{~s}^{-1}$ ). Carbonaceous combustion aerosol from pollution sources increases CDNC over Europe, US and Asia more than $100 \%$ (maximum $300 \%$ ) and by 10-20\% over much of the North Atlantic. At atmospheric pressures where low cloud typically occurs $(800-950 \mathrm{mb}$ ), zonal mean annual average all-sky CDNC are $50-250 \mathrm{~cm}^{-3}$ (Fig. 5), a range in agreement with previous simulations (e.g., Chen and Penner, 2005).

There are important microphysical responses that occur when carbonaceous combustion aerosol is removed which act to reduce the impact of emissions reduction on CDNC. The presence of carbonaceous combustion aerosol actually leads to a $5 \%$ reduction in CDNC in the upper troposphere (Fig. 5d) because it acts as a condensational sink for sulfuric acid vapour leading to reduced new particle formation and growth. As a result of atmospheric transport, this effect leads to a $1-5 \%$ reduction in CDNC in the remote oceanic $\mathrm{BL}$ and south of $50^{\circ} \mathrm{S}$. However, this effect is more than compensated for by direct emissions of carbonaceous combustion aerosol and global mean CDNC in low-level clouds (800$950 \mathrm{hPa}$ ) increases by $38 \%$.

The contribution of carbonaceous combustion aerosol to CDNC was then used to quantify the AIE. We calculated the cloud-albedo AIE at the top of the atmosphere by comparing the cloud albedo calculated from a perturbed model 
(a)

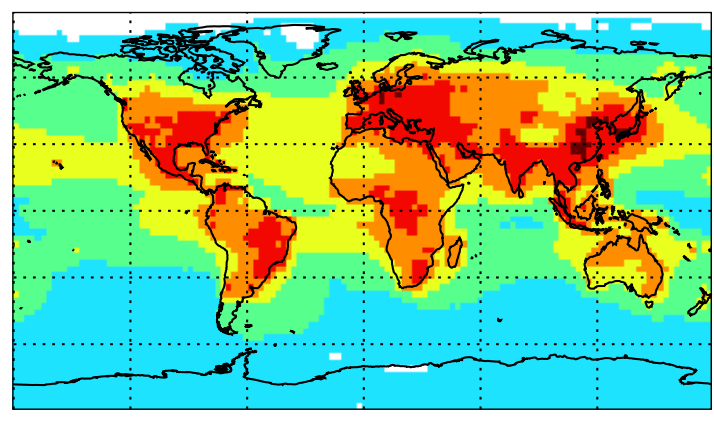

$20 \quad 38 \quad 74 \quad 143 \quad 277 \quad 536 \quad 10352000 \quad \mathrm{~cm}^{-3}$

(c)

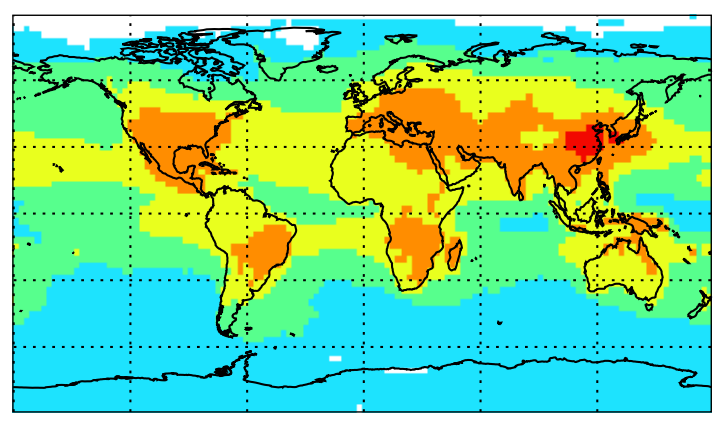

$20 \quad 38 \quad 74 \quad 143 \quad 277 \quad 536 \quad 10352000 \quad \mathrm{~cm}^{-3}$ (b)

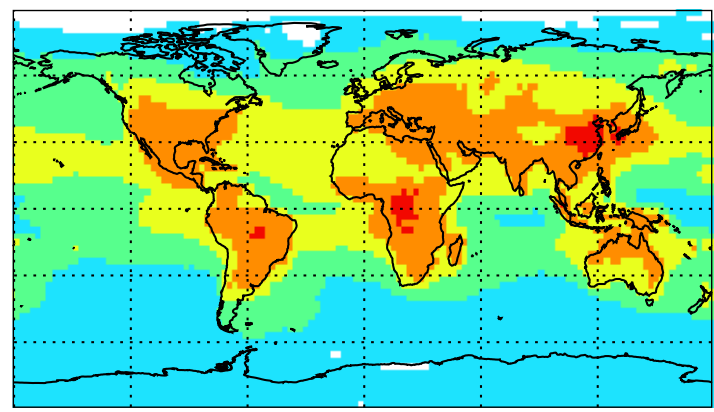

$20 \quad 38 \quad 74 \quad 143 \quad 277 \quad 536 \quad 10352000 \quad \mathrm{~cm}^{-3}$

(d)

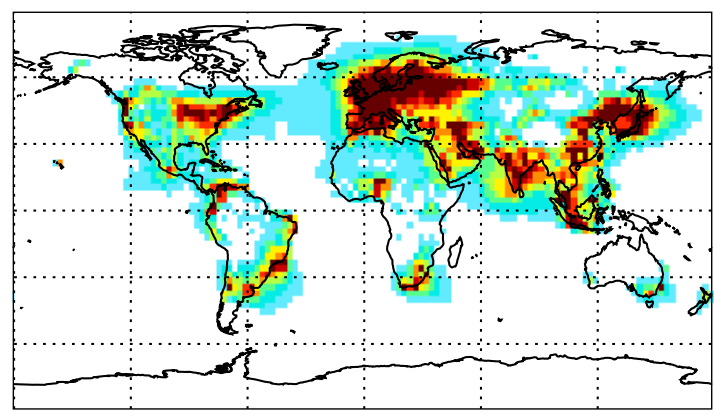

$0 \quad 102030405060708090100 \%$

Fig. 4. Simulated all-sky annual mean cloud droplet number concentrations (CDNC) at the surface. (a) With carbonaceous combustion aerosol, (b) without pollution (fossil fuel and biofuel) carbonaceous combustion aerosol emissions, (c) without carbonaceous combustion aerosol emissions. (d) Percentage change in CDNC due to pollution carbonaceous combustion aerosol emissions. All results are for a cloud updraft velocity of $0.4 \mathrm{~m} \mathrm{~s}^{-1}$.

simulation to the cloud albedo calculated from an unperturbed simulation. The unperturbed simulation includes carbonaceous combustion aerosol emissions (CCA). In the perturbed simulations emissions of carbonaceous combustion aerosol had been removed.

We used monthly mean climatological cloud fields and surface albedo (averaged over the period 1983-2005) from the International Satellite Cloud Climatology Project (ISCCP) (Rossow and Schiffer, 1999), together with the off-line version of the Edwards and Slingo (1996) radiative transfer model. This model uses 9 bands in the longwave and 6 bands in the shortwave and a delta-Eddington 2 stream scattering solver at all wavelengths. In our climatology, the clouds were added to three unique vertical levels, corresponding to low and middle and high clouds. Water vapour, temperature and ozone data are based on ECMWF reanalysis data (see Rap et al., 2010 for details). For the unperturbed and perturbed runs, cloud effective drop radius $r_{\mathrm{e}}$ (in $\mu \mathrm{m}$ ) for low and mid level water clouds was calculated from the
GLOMAP CDNC (in $\mathrm{cm}^{-3}$ ) and ISCCP derived liquid water paths (LWP, in $\mathrm{g} \mathrm{m}^{-2}$ ), using the Bower et al. (1994) parameterisation, namely:

$r_{\mathrm{e}}=100 \times\left[\mathrm{LWP} /(\Delta z) \times 3 /\left(4 \pi \times \rho_{\mathrm{W}} \times \mathrm{CDNC}\right)\right]^{1 / 3}$,

where $\Delta z$ is the cloud thickness, which in our climatology is roughly $1400 \mathrm{~m}$ and $2900 \mathrm{~m}$ for low and middle clouds, respectively and $\rho_{\mathrm{w}}$ (in $\mathrm{g} \mathrm{cm}^{-3}$ ) is the density of liquid water. Only water clouds were modified. Note that in its derivation of LWP, ISCCP assumes a constant effective radius of $10 \mu \mathrm{m}$. This creates an inconsistency between our method and the original ISCCP retrieval. To investigate this our results were compared to an alternative approach, where a control effective radius of $r_{\mathrm{e} 1}=10 \mu \mathrm{m}$ was employed in the unperturbed experiment. For the perturbed experiment the effective radius $r_{\mathrm{e} 2}$ was scaled to account for the drop volume change (needed to maintain the same water content) caused from the GLOMAP CDCN change, i.e. $r_{\mathrm{e} 2}=$ 
(a)

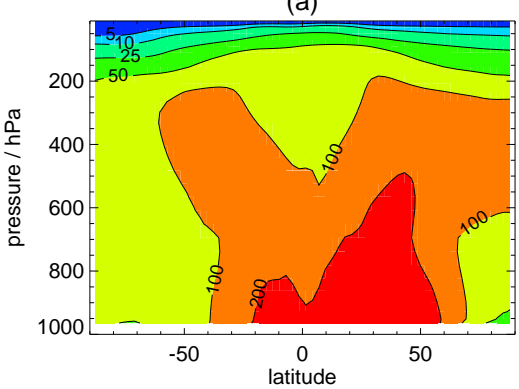

(c)

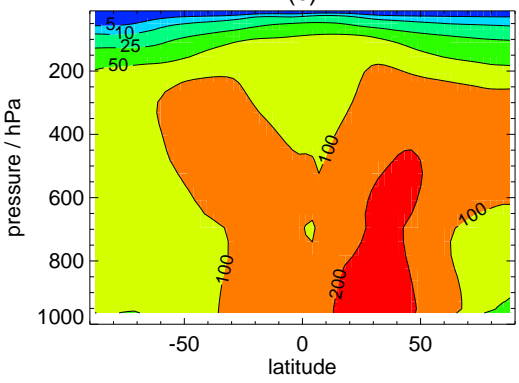

(b)

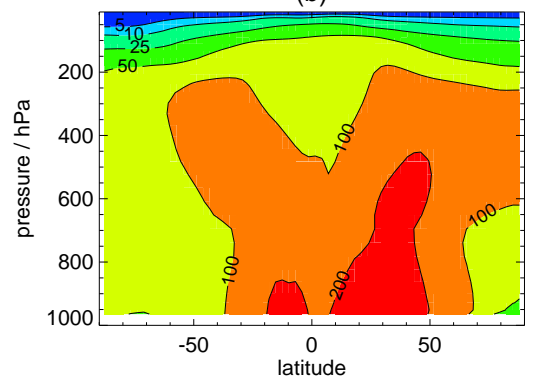

(d)

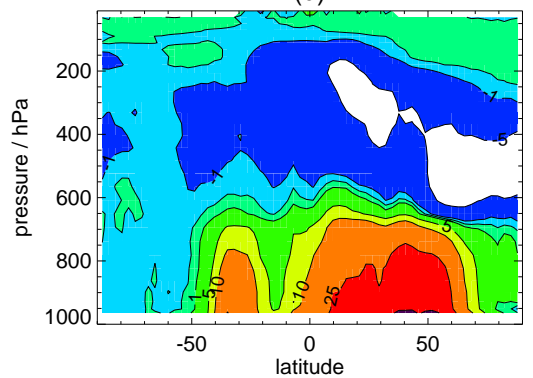

Fig. 5. Simulated zonal mean all-sky annual average cloud droplet number concentrations (CDNC) (in $\mathrm{cm}^{-3}$ ) for a range of model simulations. (a) Including carbonaceous combustion aerosol emissions, (b) without pollution (fossil fuel and biofuel) carbonaceous combustion aerosol emissions, (c) without carbonaceous combustion aerosol emissions, (d) percentage change in zonal mean CDNC due to pollution carbonaceous combustion aerosol (contour intervals: $-5 \%,-1 \%, 0 \%, 1 \%, 5 \%, 10 \%, 25 \%, 50 \%$ ).

$r_{\mathrm{e} 1} \times\left(\mathrm{CDNC}_{1} / \mathrm{CDNC}_{2}\right)^{1 / 3}$. Both approaches gave very similar answers, suggesting the methodology is robust.

We evaluated the sensitivity of our calculated AIE due to likely uncertainties in two parameters (Table 5):

1. Updraft velocity: the global distribution of cloud updraft velocity is uncertain. For this reason we calculated the AIE at 5 different updraft velocities $(0.1$ to $\left.0.5 \mathrm{~m} \mathrm{~s}^{-1}\right)$. At faster cloud updraft velocities $(0.2$ to $0.5 \mathrm{~m} \mathrm{~s}^{-1}$ ) uncertainty in the updraft velocity changes the calculated AIE by less than $15 \%$. Slower updraft velocities introduce up to a factor 2 uncertainty in the AIE. The standard deviation in annual global mean AIE calculated across the cloud updraft velocities is $0.08 \mathrm{~W} \mathrm{~m}^{-2}$ for all carbonaceous combustion aerosol and $0.03 \mathrm{~W} \mathrm{~m}^{-2}$ for fossil fuel and biofuel carbonaceous combustion aerosol.

2. Size distribution of emitted carbonaceous combustion particles: to test this sensitivity we used simulation small_CCA as the unperturbed simulation in place of CCA. In this simulation carbonaceous combustion aerosol are assumed to be emitted at smaller sizes (see Table 3). For the perturbed simulation we used no_CCA as before. When carbonaceous combustion aerosol is emitted at these smaller sizes the AIE of all carbonaceous combustion aerosol is $-1.08 \mathrm{~W} \mathrm{~m}^{-2}$. The standard deviation across the five cloud updraft velocities was $0.11 \mathrm{~W} \mathrm{~m}^{-2}$.
We therefore found that the dominant source of uncertainty in our calculation of the AIE is the uncertainty in the size distribution of emitted carbonaceous combustion aerosol (lower and upper estimates: $-0.34 \mathrm{~W} \mathrm{~m}^{-2}$ and $-1.08 \mathrm{~W} \mathrm{~m}^{-2}$, respectively) rather than the uncertainty in supersaturation or cloud updraft (range: $-0.2 \mathrm{~W} \mathrm{~m}^{-2}$ to $-0.39 \mathrm{~W} \mathrm{~m}^{-2}$ ). Including the light absorption by $\mathrm{BC}$ would not change our AIE by more than $0.07 \mathrm{~W} \mathrm{~m}^{-2}$ (Chuang et al., 2002). Additional sources of uncertainty will be due to uncertainty in the cloud retrievals from the ISCCP. ISCCP is likely to underestimate the amount of low-level cloud (Weare, 2000), so our estimate of AIE is likely to be biased slightly low.

Figure 6 shows the AIE due to pollution carbonaceous combustion aerosol emissions. Regional radiative effects as large as $-5 \mathrm{~W} \mathrm{~m}^{-2}$ are calculated within and downwind of polluted regions. Figure 7 shows the annual average zonal mean AIE due to carbonaceous combustion aerosol. At latitudes between $35^{\circ} \mathrm{S}$ and $55^{\circ} \mathrm{N}$ we calculate a zonal mean radiative effect at the top of the atmosphere as large as $-1.5 \mathrm{~W} \mathrm{~m}^{-2}$ (when we assume smaller sized carbonaceous combustion particles) in agreement with Chen and Penner (2005).

We calculated the average AIE across the five updraft speeds assuming that each updraft speed occurs with equal probability. When we assumed the larger emission size of carbonaceous combustion aerosol we calculated that the global annual mean AIE due to all carbonaceous combustion 
Table 5. Calculated global mean top-of-atmosphere aerosol indirect effect (AIE) due to carbonaceous combustion aerosol for a range of cloud updraft velocities. Model experiments as described in Table 3. The perturbed and unperturbed simulations are detailed in the table.

\begin{tabular}{lrrr}
\hline & \multicolumn{3}{c}{ AIE/W m ${ }^{-2}$} \\
\cline { 2 - 4 } $\begin{array}{c}\text { Updraft } \\
\text { velocity } \\
\left(\mathrm{m} \mathrm{s}^{-1}\right)\end{array}$ & $\begin{array}{r}\text { CCA versus } \\
\text { no_CCA }\end{array}$ & $\begin{array}{r}\text { small_CCA } \\
\text { versus no_CCA }\end{array}$ & $\begin{array}{r}\text { CCA versus } \\
\text { no_ff_bf_CCA }\end{array}$ \\
\hline 0.1 & & & \\
0.2 & -0.20 & -0.88 & -0.19 \\
0.3 & -0.34 & -1.10 & -0.22 \\
0.4 & -0.38 & -1.15 & -0.25 \\
0.5 & -0.39 & -1.15 & -0.25 \\
\hline MEAN & -0.39 & -1.13 & -0.25 \\
\hline
\end{tabular}

aerosol is $-0.34 \mathrm{~W} \mathrm{~m}^{-2}$. We calculated that the global mean AIE due to pollution sources (fossil fuel and biofuel) carbonaceous combustion aerosol is $-0.23 \mathrm{~W} \mathrm{~m}^{-2}$. In comparison, the AIE calculated by our model for all anthropogenic aerosol is $-1.2 \mathrm{~W} \mathrm{~m}^{-2}$. The small size of emitted fossil fuel carbonaceous combustion aerosol compared to those from wildfire and biofuel sources means that they contribute more to CDNC and AIE per unit mass of emission: whilst pollution sources account for only $31 \%$ of the total emitted mass of carbonaceous combustion aerosol (Table 2) they contribute $75 \%$ of the enhancement to CDNC and two-thirds of the AIE (Tables 4 and 5). Our calculated AIE is smaller than the recent estimate from Chen et al. (2010) of $+0.31 \mathrm{~W} \mathrm{~m}^{-2}$ for a $50 \%$ reduction in carbonaceous combustion aerosol emissions, but is the first to have been evaluated using a global dataset of cloud-forming particles.

\section{Conclusions}

We have synthesised observations reported in the published literature to produce a worldwide dataset (277 mean observations from 55 published studies) of cloud condensation nuclei $(\mathrm{CCN})$ concentrations. We used the dataset along with the GLOMAP global aerosol microphysics model to explore the contribution of carbonaceous combustion aerosol to $\mathrm{CCN}$. We find that the model is biased low (normalised mean bias $=-77 \%$ ) unless carbonaceous combustion aerosol is able to act as CCN. Uncertainty in the emitted size distribution of carbonaceous combustion aerosol results in a substantial uncertainty in the contribution of this aerosol source to global CCN. When we use the emission size suggested by AeroCom (Dentener et al., 2006) carbonaceous combustion aerosol contributes $64 \%$ to simulated global CCN concentrations. Using a larger emission size (Stier et al., 2005) reduces the calculated contribution of carbonaceous combustion aerosol to global CCN to $52 \%$.

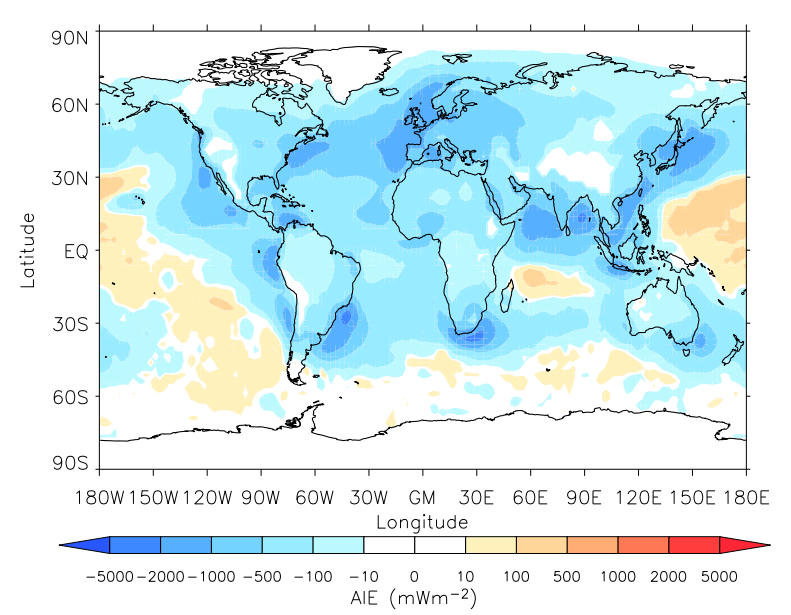

Fig. 6. Annual mean net (long wave and short wave) top of atmosphere cloud-albedo aerosol indirect effect (AIE) due to pollution (fossil fuel and biofuel) carbonaceous combustion aerosol for a cloud updraft velocity of $0.4 \mathrm{~m} \mathrm{~s}^{-1}$.

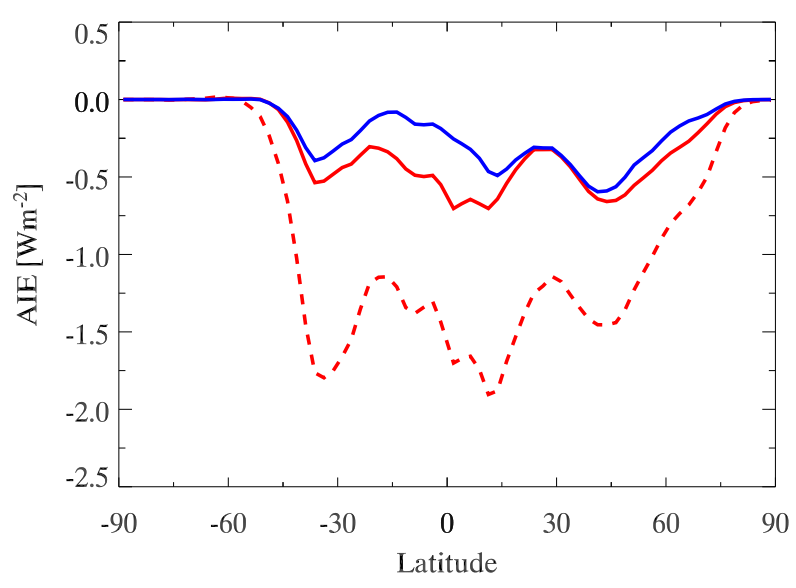

Fig. 7. Zonal annual mean cloud albedo aerosol indirect effect (AIE) due to carbonaceous combustion aerosol. The AIE is shown for all carbonaceous combustion aerosol (red line) and for pollution (fossil fuel and biofuel) carbonaceous combustion aerosol (blue line). The red dashed line shows the AIE for all carbonaceous combustion aerosol when we assume that they are emitted at smaller particle sizes (small_CCA). See Table 3 for description of model experiments.

We calculated the first (cloud albedo) aerosol indirect effect due to carbonaceous combustion aerosol. We do not calculate the second (cloud lifetime) aerosol indirect effect or semi-direct effects. Therefore our study should not be used to calculate the overall impact of carbonaceous combustion aerosol on climate. Furthermore, since different aerosol effects are unlikely to linearly combine care should be taken when comparing the forcing numbers calculated here with those from other studies. We calculated a global mean top of atmosphere first aerosol indirect effect due to carbonaceous 
combustion aerosol (from fossil fuel, biofuel and wildfire) of $-0.34 \mathrm{~W} \mathrm{~m}^{-2}$ when we assumed particles are emitted at larger sizes and $-1.08 \mathrm{~W} \mathrm{~m}^{-2}$ when we assumed the smaller emitted size. This large sensitivity to particle size underlines the importance of improving emission databases to include the emitted particle size distribution and the need to understand sub-grid evolution of particle size distributions from emission source to the regional scale (Pierce et al., 2009).

Different emission sources emit carbonaceous combustion particles with different size distributions. The smaller particle size of fossil fuel carbonaceous combustion emissions means that they contribute more to $\mathrm{CCN}$ concentrations than biomass burning emissions per unit mass of emission. We find that whilst pollution (fossil and biofuel) emission sources only account for $31 \%$ of the total emitted mass of carbonaceous combustion aerosol they account for $75 \%$ of the simulated enhancement in cloud droplet number concentrations (CDNC). This greater contribution of pollution sources to CDNCs means that they contribute substantially to the overall AIE due to carbonaceous combustion aerosol. We calculated that carbonaceous combustion aerosol from pollution sources result in a aerosol indirect effect of $-0.23 \mathrm{~W} \mathrm{~m}^{-2}$ (when we assume particles are emitted at larger sizes) which is two thirds of the total aerosol indirect effect we attribute to all carbonaceous combustion aerosol. Model studies that calculate the AIE of carbonaceous combustion aerosol but do not simulate the aerosol size distribution (e.g., Unger et al., 2010) may overestimate the AIE attributed to biomass burning sources and underestimate the AIE attributed to fossil fuel sources.

Previous discussion of reductions in black carbon (BC) emissions to mitigate climate change have emphasised the value of cutting emissions where the mass of $\mathrm{BC}$ is high relative to other aerosol components (Grieshop et al., 2009; Ramana et al., 2010). For example, some fossil fuels (residential burning of solid fuels and diesel engines) emit a high proportion of $\mathrm{BC}$ compared to biofuel and biomass burning, making them attractive for emissions reductions to slow global warming. While consideration of the BC mass fraction may be sufficient for estimating the direct aerosol forcing of carbonaceous combustion aerosol, our study shows that mitigation strategies need to take account of the impact on the size distribution and number concentration of emitted carbonaceous combustion aerosol and the fact that BC and primary organic matter are present in the same particle, which shifts the technological challenge considerably. Many fossil fuel sources emit large numbers of small carbonaceous combustion aerosol which have a substantial impact on cloud albedo. Reductions in carbonaceous combustion aerosol emissions to slow global warming would be premature before these particle number concentration effects are quantified, taking into account the non-linear response of atmospheric CCN to changes in emissions, which are potentially substantial (Merikanto et al., 2009).
Some previous studies (Jacobson, 2002, 2004, 2006, 2010) that have attempted to include a diverse range of aerosol direct, indirect and semi-direct effects have concluded that carbonaceous combustion aerosols have a net positive warming impact on climate. It is now necessary to evaluate the predictions of such models against new datasets of cloud drop forming particles that have been synthesised here.

Acknowledgements. This work was funded through UK Natural Environmental Research Council (NERC) grants (NE/G015015/1, NE/G005109/1). We also acknowledge a British Council Academic Research Collaboration grant (4500541720). We thank Jeff Pierce and an anonymous reviewer for their comments on our manuscript.

Edited by: R. Krejci

\section{References}

Adams, P. J. and Seinfeld, J. H.: Predicting global aerosol size distributions in general circulation models, J. Geophys. Res., 107(D19), 4370, doi:10.1029/2001JD001010, 2002.

Adhikari, M., Ishizaka, Y., Minda, H., Kazaoka, R., Jensen, J. B., and Gras, J. L.: Vertical distribution of cloud condensation nuclei concentrations and their effect on microphysical properties of clouds over the sea near the southwest islands of Japan, J. Geophys. Res., 110(D10), D10203, doi:10.1029/2004JD004758, 2005.

Allan, J. D., Baumgardner, D., Raga, G. B., Mayol-Bracero, O. L., Morales-García, F., García-García, F., Montero-Martínez, G., Borrmann, S., Schneider, J., Mertes, S., Walter, S., Gysel, M., Dusek, U., Frank, G. P., and Krämer, M.: Clouds and aerosols in Puerto Rico - a new evaluation, Atmos. Chem. Phys., 8, 12931309, doi:10.5194/acp-8-1293-2008, 2008.

Andreae, M. O.: Correlation between cloud condensation nuclei concentration and aerosol optical thickness in remote and polluted regions, Atmos. Chem. Phys., 9, 543-556, doi:10.5194/acp-9-543-2009, 2009.

Andreae, M. O. and Rosenfeld, D.: Aerosol-cloud-precipitation interactions. Part 1, The nature and sources of cloud-active aerosols, Earth-Sci. Rev., 89, 13-41, 2008.

Andreae, M. O., Elbert, W., and de Mora, S.: Biogenic sulfur emissions and aerosols over the tropical South Atlantic 3. Atmospheric dimethylsulfide, aerosols and cloud condensation nuclei, J. Geophys. Res., 100(D6), 11335-11356, doi:10.1029/94JD02828, 1995.

Andreae, M. O., Rosenfeld, D., Artaxo, P., Costa, A. A., Frank, G. P., Longo, K. M., and Silva-Dias, M. A. F.: Smoking rain clouds over the Amazon, Science, 303, 1337, doi:10.1126/science.1092779, 2004.

Arneth, A., Unger, N., Kulmala, M., and Andreae, M. O.: Clean the air, heat the planet, Science, 326, 672-673, 2009.

Arnold, S. A., Chipperfield, M. P., and Blitz, M. A.: A threedimensional model study of the effect of new temperaturedependent quantum yields for acetone photolysis, J. Geophys. Res., 110(D22), D22305, doi:10.1029/2005JD005998, 2005. 
Ayers, G. P. and Gras, J. L.: Seasonal relationship between cloud condensation nuclei and aerosol methanesulphonate in marine air, Nature, 353, 834-835, 1991.

Ayers, G. P., Cainey, J. M., Gillett, R. W., and Ivey, J. P.: Atmospheric sulphur and cloud condensation nuclei in marine air in the Southern Hemisphere, Philos. T. Roy. Soc. Lond. B, 352, 203-211, 1997.

Ban-Weiss, G. A., Cao, L., Bala, G., and Caldeira, K.: Dependence of climate forcing and response on the atitude of black carbon aerosols, Clim. Dyn., doi:10.1007/s00382-011-1052-y, 2011.

Bauer, S. E., Menon, S., Koch, D., Bond, T. C., and Tsigaridis, K.: A global modeling study on carbonaceous aerosol microphysical characteristics and radiative effects, Atmos. Chem. Phys., 10, 7439-7456, doi:10.5194/acp-10-7439-2010, 2010.

Baumgardner, D., Raga, G. B., and Muhlia, A.: Evidence for the formation of CCN by photochemical processes in Mexico City, Atmos. Environ., 38, 357-367, 2004.

Bond, T. C.: Can warming particles enter global climate discussions?, Environ. Res. Lett., 2, 045030, doi:10.1088/17489326/2/4/045030, 2007.

Bond, T. C. and Sun, H.: Can reducing black carbon emissions counteract global warming, Environ. Sci. Technol., 39, 59215926, 2005.

Bond, T. C., Streets, D. G., Yarber, K. F., Nelson, S. M., Woo, J.H., and Klimont, Z.: A technology-based global inventory of black and organic carbon emissions from combustion, J. Geophys. Res., 109, D14203, doi:10.1029/2003JD003697, 2004.

Bougiatioti, A., Fountoukis, C., Kalivitis, N., Pandis, S. N., Nenes, A., and Mihalopoulos, N.: Cloud condensation nuclei measurements in the marine boundary layer of the Eastern Mediterranean: CCN closure and droplet growth kinetics, Atmos. Chem. Phys., 9, 7053-7066, doi:10.5194/acp-9-7053-2009, 2009.

Bower, K. N., Moss, S. J., Johnson, D. W., Choularton, T. W., Latham, J., Brown, P. R. A., Blyth, A. M., and Cardwell, J.: A parameterization of warm clouds for use in atmospheric general circulation models, J. Atmos. Sci., 51, 2722-2732, 1994.

Broekhuizen, K., Chang, R. Y.-W., Leaitch, W. R., Li, S.-M., and Abbatt, J. P. D.: Closure between measured and modeled cloud condensation nuclei (CCN) using size-resolved aerosol compositions in downtown Toronto, Atmos. Chem. Phys., 6, 2513-2524, doi:10.5194/acp-6-2513-2006, 2006.

Cantrell, W., Shaw, G., Leek, C., Granat, L., and Cachier, H.: Relationships between cloud condensation nuclei spectra and aerosol particles on a south-north transect of the Indian Ocean, J. Geophys. Res., 105(D12), 15313-15320, doi:10.1029/2000JD900219, 2000.

Cantrell, W., Shaw, G., Cass, G. R., Chowdhury, Z., Hughes, L. S., Prather, K. A., Guazzotti, S. A., and Coffee, K. R.: Closure between aerosol particles and cloud condensation nuclei at Kaashidhoo Climate Observatory, J. Geophys. Res., 106(D22), 28711-28718, doi:10.1029/2000JD900781, 2001.

Chang, R. Y.-W., Slowik, J. G., Shantz, N. C., Vlasenko, A., Liggio, J., Sjostedt, S. J., Leaitch, W. R., and Abbatt, J. P. D.: The hygroscopicity parameter $(\kappa)$ of ambient organic aerosol at a field site subject to biogenic and anthropogenic influences: relationship to degree of aerosol oxidation, Atmos. Chem. Phys., 10, 50475064, doi:10.5194/acp-10-5047-2010, 2010.

Chen, Y. and Penner, J. E.: Uncertainty analysis for estimates of the first indirect aerosol effect, Atmos. Chem. Phys., 5, 2935-2948, doi:10.5194/acp-5-2935-2005, 2005.

Chen, W.-T., Lee, Y. H., Adams, P. J., Nenes, A., and Seinfeld, J. H.: Will black carbon mitigation dampen aerosol indirect forcing?, Geophys. Res. Lett., 37, L09801, doi:10.1029/2010GL042886, 2010.

Chipperfield, M. P.: New version of the TOMCAT/SLIMCAT offline chemical transport model: Intercomparison of stratospheric tracer experiments, Q. J. Roy. Meteorol. Soc., 132, 1179-1203, doi:10.1256/qj.05.51, 2006.

Chuang, P. Y., Collins, D. R., Pawlowska, H., Snider, J. R., Jonsson, H. H., Brenguier, J. L., Flagan, R. C., and Seinfeld, J. H.: CCN measurements during ACE-2 and their relationship to cloud microphysical properties, Tellus, 52B, 843-867, 2000.

Chuang, C. C., Penner, J. E., Prospero, J. M., Grant, K. E., Rau, G. H., and Kawamoto, K.: Cloud susceptibility and the first aerosol indirect forcing: Sensitivity to black carbon and aerosol concentrations, J. Geophys. Res., 107(D21), 4564, doi:10.1029/2000JD000214, 2002.

Chung, S. H. and Seinfeld, J. H.: Global distribution and climate forcing of carbonaceous aerosols, J. Geophys. Res., 107(D19), 4407, doi:10.1029/2001JD001397, 2002.

Chung, C., Ramanathan, V., Kim, D., and Podgorny, I. A.: Global anthropogenic aerosol direct forcing derived from satellite and ground-based observations, J. Geophys. Res., 110, D24207, doi:10.1029/2005JD006356, 2005.

Conant, W. C., VanReken, T. M., Rissman, T. A., Varutbangkul, V., Jonsson, H. H., Nenes, A., Jimenez, J. L., Delia, A. E., Bahreini, R., Roberts, G. C., Flagan, R. C., and Seinfeld, J. H.: Aerosolcloud drop concentration closure in warm cumulus, J. Geophys. Res., 109(D13), D13204, doi:10.1029/2003JD004324, 2004.

Defelice, T. P., Saxena, V. K., and Shaocai, Y.: On the measurements of cloud condensation nuclei at Palmer station, Antarctica, Atmos. Environ., 31(23), 4039-4044, 1997.

Delene, D. J. and Deshler, T.: Calibration of a photometric cloud condensation nucleus counter designed for deployment on a balloon package, J. Atmos. Oceanic Technol., 17, 459-467, 2000.

Delene, D. and Deshler, T.: Vertical profiles of cloud condensation nuclei above Wyoming, J. Geophys. Res., 106(D12), 12579_ 12588, doi:10.1029/2000JD900800, 2001.

Delene, D. J., Deshler, T., Wechsler, P., and Vali, G. A.: A balloonborne cloud condensation nuclei counter, J. Geophys. Res., 103, 8927-8934, 1998.

DeMott, P. J., Chen, Y., Kreidenweis, S. M., Rogers, D. C., and Sherman, D. E.: Ice formation by black carbon particles, Geophys. Res. Lett., 26(16), 2429-2432, 1999.

Dentener, F., Kinne, S., Bond, T., Boucher, O., Cofala, J., Generoso, S., Ginoux, P., Gong, S., Hoelzemann, J. J., Ito, A., Marelli, L., Penner, J. E., Putaud, J.-P., Textor, C., Schulz, M., van der Werf, G. R., and Wilson, J.: Emissions of primary aerosol and precursor gases in the years 2000 and 1750 prescribed data-sets for AeroCom, Atmos. Chem. Phys., 6, 4321-4344, doi:10.5194/acp6-4321-2006, 2006.

Désalmand, F.: An attempt to characterise a relationship between supersaturation spectrum, size spectrum and solubility of CCN observed over a tropical rain forest, J. Atmos. Sci., 42(5), 472477, 1985.

Dusek, U., Frank, G. P., Hildebrandt, L., Curtius, J., Schneider, J., Walter, S., Chand, D., Drewnick, F., Hings, S., Jung, D., Borrmann, S., and Andreae, M. O.: Size matters more than chemistry 
for cloud-nucleating ability of aerosol particles, Science, 312, 1375, doi:10.1126/science.1125261, 2006.

Edwards, J. M. and Slingo, A.: Studies with a flexible new radiation code: I. Choosing a configuration for a large scale model, Q. J. Roy. Meteorol. Soc., 122, 689-720, doi:10.1002/qj.49712253107, 1996.

Elliot, W. P. and Egami, R.: CCN measurements over the ocean, J. Atmos. Sci., 32, 371-374, 1975.

Fitzgerald, J. W., Rogers, C. F., and Hudson, J. G.: Review of Isothermal Haze Chamber Performance, J. Rech. Atmos., 15, 333-346, 1981.

Forster, P., Ramaswamy, V., Artaxo, P., Berntsen, T., Betts, R., Fahey, D. W., Haywood, J., Lean, J., Lowe, D. C., Myhre, G., Nganga, J., Prinn, R., Raga, G., Schulz, M., and Van Dorland, R.: Changes in Atmospheric Constituents and in Radiative Forcing, in: Climate Change 2007: The Physical Science Basis. Contribution of Working Group I to the Fourth Assessment Report of the Intergovernmental Panel on Climate Change, edited by: Solomon, S., Qin, D., Manning, M., Chen, Z., Marquis, M., Averyt, K. B., Tignor, M., and Miller, H. L., Cambridge University Press, Cambridge, United Kingdom and New York, NY, USA, 2007.

Frank, G. P., Dusek, U., and Andreae, M. O.: Technical Note: Characterization of a static thermal-gradient $\mathrm{CCN}$ counter, Atmos. Chem. Phys., 7, 3071-3080, doi:10.5194/acp-7-3071-2007, 2007.

Fukuta, N. and Saxena, V. K.: The principle of a new horizontal thermal gradient cloud condensation nucleus spectrometer, J. Rech. Atmos., 13, 169-188, 1979a.

Fukuta, N. and Saxena, V. K.: A horizontal thermal gradient cloud condensation nucleus spectrometer, J. Appl. Meteorol., 18, 1352-1362, 1979b.

Gong, S. L.: A parameterization of sea-salt aerosol source function for sub- and super-micron particles, Global Biogeochem. Cy., 17(4), 1097, doi:10.1029/2003GB002079, 2003.

Grieshop, A. P., Reynolds, C. C. O., Kandlikar, M., and Dowlatabadi, H.: A black-carbon mitigation wedge, Nat. Geosci. 2, 533-534, 2009.

Guenther, A., Hewitt, C. N., Erickson, D., Fall, R., Geron, C., Graedel, T., Harley, P., Klinger, L., Lerdau, M., McKay, W. A., Pierce, T., Scholes, B., Steinbrecher, R., Tallamraju, R., Taylor, J., and Zimmerman, P.: A Global-Model of Natural Volatile Organic-Compound Emissions, J. Geophys. Res., 100(D5), 8873-8892, 1995.

Gunthe, S. S., King, S. M., Rose, D., Chen, Q., Roldin, P., Farmer, D. K., Jimenez, J. L., Artaxo, P., Andreae, M. O., Martin, S. T., and Pöschl, U.: Cloud condensation nuclei in pristine tropical rainforest air of Amazonia: size-resolved measurements and modeling of atmospheric aerosol composition and CCN activity, Atmos. Chem. Phys., 9, 7551-7575, doi:10.5194/acp-9-75512009, 2009.

Hansen, J., Sato, M., and Ruedy, R.: Radiative forcing and climate response, J. Geophys. Res., 102, 6831-6864, 1997.

Hansen, J., Sato, M., Ruedy, R., Nazarenko, L., Lacis, A., Schmidt, G. A., Russell, G., Aleinov, I., Bauer, M., Bauer, S., Bell, N., Cairns, B., Canuto, V., Chandler, M., Cheng, Y., Del Genio, A., Faluvegi, G., Fleming, E., Friend, A., Hall, T., Jackman, C., Kelley, M., Kiang, N., Koch, D., Lean, J., Lerner, J., Lo, K., Menon, S., Miller, R., Minnis, P., Novakov, T., Oinas, V., Perlwitz, J.,
Perlwitz, J., Rind, D., Romanou, A., Shindell, D., Stone, P., Sun, S., Tausnev, N., Thresher, D., Wielicki, B., Wong, T., Yao, M., and Zhang, S.: Efficacy of climate forcings, J. Geophys. Res., 110, D18, doi:10.1029/2005JD005776, 2005.

Hansen, J., Sato, M., Kharecha, P., Russell, G., Lea, D. W., and Siddall, M.: Climate change and trace gases, Philos. T. Roy. Soc. A., 365, 1856, 1925-1954, 2007.

Hegg, D., Radke, L., and Hobbs, P.: Measurements of Aitken nuclei and cloud condensation nuclei in the marine atmosphere and their relation to the DMS-cloud-climate hypothesis, J. Geophys. Res., 96(D10), 18727-18733, doi:10.1029/91JD01870, 1991.

Hegg, D., Ferek, R., and Hobbs, P.: Light scattering and cloud condensation nucleus activity of sulphate aerosol measured over the Northeast Atlantic Ocean, J. Geophys. Res., 98(D8), 1488714894, doi:10.1029/93JD01615, 1993.

Hegg, D. A., Ferek, R. J., and Hobbs, P. V.: Cloud condensation nuclei over the Arctic Ocean in early spring, J. Appl. Meteorol., 34, 2076-2082, 1995.

Hegg, D., Hobbs, P., Gassó, S., Nance, J., and Rangno, A.: Aerosol measurements in the Arctic relevant to direct and indirect radiative forcing, J. Geophys. Res., 101(D18), doi:10.1029/96JD02246, 1996.

Hitzenberger, R., Berner, A., Giebl, H., Kromp, R., Larson, S. M. Rouc, A., Koch, A., Marischka, S., and Puxbaum, H.: Contribution of carbonaceous material to cloud condensation nuclei concentrations in European background (Mt. Sonnblick) and urban (Vienna) aerosols, Atmos. Environ. 33(17), 2647-2659, 1999.

Hoppel, W. A.: Measurement of the size distribution and CCN supersaturation spectrum of submicron aerosols over the ocean, J. Atmos. Sci., 36, 2006-2015, 1979.

Hoppel, W. A., Twomey, S., and Wojciechowski, T. A.: A segmented thermal gradient diffusion chamber for continuous measurements of CN, J. Aerosol Sci., 10, 369-373, 1979.

Hudson, J. G.: An instantaneous CCN spectrometer, J. Atmos. Oceanic Technol., 6, 1055-1065, 1989.

Hudson, J.: Cloud condensation nuclei near marine cumulus, J. Geophys. Res., 98(D2), 2693-2702, doi:10.1029/92JD02169, 1993.

Hudson, J. G. and Alofs, D. J.: Performance of continuous flow diffusion chambers, J. Rech. Atmos., 5, 321-331, 1981.

Hudson, J. G. and Frisbie, P. R.: Surface cloud condensation nuclei and condensation nuclei measurements at Reno, Nevada, Atmos. Environ., 25A(10), 2285-2299, 1991a.

Hudson, J. and Frisbie, P.: Cloud condensation nuclei near marine stratus, J. Geophys. Res., 96(D11), 20795-20808, doi:10.1029/91JD02212, 1991b.

Hudson, J. G. and Squires, P.: An improved continuous flow diffusion cloud chamber, J. Appl. Meteorol., 15, 776-782, 1976.

Hudson, J. G. and Squires, P.: Continental surface measurements of CCN flux, J. Atmos. Sci., 35, 1289-1295, 1978.

Hudson, J. and Xie, Y.: Vertical distributions of cloud condensation nuclei spectra over the summertime northeast Pacific and Atlantic Oceans, J. Geophys. Res., 104(D23), 30219-30229, doi:10.1029/1999JD900413, 1999.

Hudson, J. G. and Yum, S. S.: Maritime-continental drizzle contrasts in small cumuli, J. Atmos. Sci., 58, 915-926, 2001.

Hudson, J. G. and Yum, S. S.: Cloud condensation nuclei spectra and polluted and clean clouds over the Indian Ocean, J. Geophys. Res., 107(D19), 8022, doi:10.1029/2001JD000829, 2002. 
Hudson, J., Xie, Y., and Yum, S.: Vertical distributions of cloud condensation nuclei spectra over the summertime Southern Ocean, J. Geophys. Res., 103(D13), 16609-16624, doi:10.1029/97JD03438, 1998.

Ishizaka Y. and Adhikari, M.: Composition of cloud condensation nuclei, J. Geophys. Res., 108(D4), 4138, doi:10.1029/2002JD002085, 2003.

Jacobson, M. Z.: Strong radiative heating due to the mixing state of black carbon in atmospheric aerosols, Nature, 409, 695-697, 2001.

Jacobson, M. Z.: Control of fossil-fuel particulate black carbon and organic matter, possibly the most effective way of slowing anthropogenic global warming, J. Geophys. Res. 107(D19), 4410, doi:10.1029/2001JD001376, 2002.

Jacobson, M. Z.: Climate response of fossil fuel and biofuel soot, accounting for soot's feedback to snow and sea ice albedo and emissivity, J. Geophys. Res., 109, D21201, doi:10.1029/2004JD004945, 2004.

Jacobson, M. Z.: Effects of externally-through-internally-mixed soot inclusions within clouds and precipitation on global climate, J. Phys. Chem., 110, 6860-6873, 2006.

Jacobson, M. Z.: Short-term effects of controlling fossil-fuel soot, biofuel soot and gases, and methane on climate, Arctic ice, and air pollution health, J. Geophys. Res., 115, D14209, doi:10.1029/2009JD013795, 2010.

Ji, Q., Shaw, G., and Cantrell, W.: A new instrument for measuring cloud condensation nuclei: Cloud Condensation Nucleus "Remover", J. Geophys. Res., 103, 28013-28019, 1998.

Johnson, D. W., Osborne, S., Wood, R., Suhre, K., Quinn, P. K., Bates, T., Andreae, M. O., Noone, K. J., Glantz, P., Bandy, B., Rudolph, J., and O'Dowd, C.: Observations of the evolution of the aerosol, cloud and boundary-layer characteristics during the 1st ACE-2 Langrangian experiment, Tellus, 52B, 348-374, 2000.

Kaufman, Y. J. and Koren, I.: Smoke and pollution aerosol effect on cloud cover, Science, 313, 655-658, doi:10.1126/science.1126232, 2006.

Kettle, A. and Andreae, M.: Flux of dimethylsulfide from the oceans: A comparison of updated data sets and flux models, J. Geophys. Res., 105(D22), 26793-26808, doi:10.1029/2000JD900252, 2000.

Koch, D. and Del Genio, A. D.: Black carbon semi-direct effects on cloud cover: review and synthesis, Atmos. Chem. Phys., 10, 7685-7696, doi:10.5194/acp-10-7685-2010, 2010.

Koch, D., Schulz, M., Kinne, S., McNaughton, C., Spackman, J. R., Balkanski, Y., Bauer, S., Berntsen, T., Bond, T. C., Boucher, O., Chin, M., Clarke, A., De Luca, N., Dentener, F., Diehl, T., Dubovik, O., Easter, R., Fahey, D. W., Feichter, J., Fillmore, D., Freitag, S., Ghan, S., Ginoux, P., Gong, S., Horowitz, L., Iversen, T., Kirkevåg, A., Klimont, Z., Kondo, Y., Krol, M., Liu, X., Miller, R., Montanaro, V., Moteki, N., Myhre, G., Penner, J. E., Perlwitz, J., Pitari, G., Reddy, S., Sahu, L., Sakamoto, H., Schuster, G., Schwarz, J. P., Seland, Ø., Stier, P., Takegawa, N., Takemura, T., Textor, C., van Aardenne, J. A., and Zhao, Y.: Evaluation of black carbon estimations in global aerosol models, Atmos. Chem. Phys., 9, 9001-9026, doi:10.5194/acp-9-9001-2009, 2009.

Koren, I., Kaufman, Y. J., Remer, L. A., and Martins, J. V.: Measurement of the effect of Amazon smoke on inhibition of cloud formation, Science, 303, 1342-1345, 2004.
Korhonen, H., Carslaw, K. S., Spracklen, D. V., Mann, G. W., and Woodhouse, M. T.: Influence of oceanic dimethyl sulfide emissions on cloud condensation nuclei concentrations and seasonality over the remote Southern Hemisphere oceans: A global model study, J. Geophys. Res.-Atmos., 113, D15204, doi:10.1029/2007JD009718, 2008a.

Korhonen, H., Carslaw, K. S., Spracklen, D. V., Ridley, D. A., Ström, J.: A global model study of processes controlling aerosol size distributions in the Arctic spring and summer, J. Geophys. Res., 113, D08211, doi:10.1029/2007JD009114, 2008b.

Kulmala, M., Laaksonen, A., and Pirjola, L.: Parameterizations for sulfuric acid/water nucleation rates, J. Geophys. Res., 103(D7), 8301-8307, 1998.

Kulmala, M., Lehtinen, K. E. J., and Laaksonen, A.: Cluster activation theory as an explanation of the linear dependence between formation rate of $3 \mathrm{~nm}$ particles and sulphuric acid concentration, Atmos. Chem. Phys., 6, 787-793, doi:10.5194/acp-6-787-2006, 2006.

Kuwata, M., Kondo, Y., Miyazaki, Y., Komazaki, Y., Kim, J. H., Yum, S. S., Tanimoto, H., and Matsueda, H.: Cloud condensation nuclei activity at Jeju Island, Korea in spring 2005, Atmos. Chem. Phys., 8, 2933-2948, doi:10.5194/acp-8-2933-2008, 2008.

Lance, S., Medina, J., Smith, J. N., and Nenes, A.: Mapping the operation of the DMT continuous flow CCN counter, Aerosol Sci. Tech., 242-254, 2006.

Lance, S., Nenes, A., Mazzoleni, C., Dubey, M. K., Gates, H., Varutbangkul, V., Rissman, T. A., Murphy, S. M., Sorooshian, A., Flagan, R. C., Seinfeld, J. H., Feingold, G., and Jonsson, H. H.: Cloud condensation nuclei activity, closure, and droplet growth kinetics of Houston aerosol during the Gulf of Mexico Atmospheric Composition and Climate Study (GoMACCS), J. Geophys. Res., 114, D00F15, doi:10.1029/2008JD011699, 2009.

Liu, P. S. K., Leaitch, W. R., Banic, C. M., Li, S.-M., Ngo, D., and Megaw, W. J.: Aerosol observations at Chebogue Point during the 1993 North Atlantic Regional Experiment: Relationships among cloud condensation nuclei, size distribution, and chemistry, J. Geophys. Res., 101(D22), 28971-28990, doi:10.1029/96JD00445, 1996.

Lohmann, U. and Feichter, J.: Global indirect aerosol effects: a review, Atmos. Chem. Phys., 5, 715-737, doi:10.5194/acp-5-7152005, 2005.

Lohmann, U., Feichter, J., Penner, J., and Leaitch, R.: Indirect effect of sulfate and carbonaceous aerosols: A mechanistic treatment, J. Geophys. Res., 105(D10), 12193-12206, 2000.

Malm, W. C., Schichtel, B. A., Pitchford, M. L., Ashbaugh, L. L., and Eldred, R. A.: Spatial and monthly trends in speciated fine particle concentration in the United States, J. Geophys. Res., 109, D03306, doi:10.1029/2003JD003739, 2004.

Manktelow, P. T., Carslaw, K. S., Mann, G. W., and Spracklen, D. V.: The impact of dust on sulfate aerosol, $\mathrm{CN}$ and $\mathrm{CCN}$ during an East Asian dust storm, Atmos. Chem. Phys., 10, 365-382, doi:10.5194/acp-10-365-2010, 2010.

McMurry, P. H.: A review of atmospheric aerosol measurements, Atmos. Environ., 34, 1959-1999, 2000.

Merikanto, J., Spracklen, D. V., Mann, G. W., Pickering, S. J., and Carslaw, K. S.: Impact of nucleation on global CCN, Atmos. Chem. Phys., 9, 8601-8616, doi:10.5194/acp-9-8601-2009, 
2009.

Merikanto, J., Spracklen, D. V., Pringle, K. J., and Carslaw, K. S.: Effects of boundary layer particle formation on cloud droplet number and changes in cloud albedo from 1850 to 2000, Atmos. Chem. Phys., 10, 695-705, doi:10.5194/acp-10-695-2010, 2010.

Metzger, A., Verheggen, B., Dommen, J., Duplissy, J., Prevot, A. S. H., Weingartner, E., Riipinen, I., Kulmala, M., Spracklen, D. V., Carslaw, K. S., and Baltensperger, U.: Atmospheric Chemistry Special Feature: Evidence for the role of organics in aerosol particle formation under atmospheric conditions, P. Natl. A. Sci., 107(15), 6646-6651, doi:10.1073/pnas.0911330107, 2010.

Nenes, A. and Seinfeld, J. H.: Parameterization of cloud droplet formation in global climate models, J. Geophys. Res., 108(D14), 4415, doi:10.1029/2002JD002911, 2003.

Nightingale, P. D., Malin, G., Law, C. S., Watson, A. J., Liss, P. S., Liddicoat, M. I., Boutin, J., and Upstill-Goddard, R. C: In Situ Evaluation of Air-Sea Gas Exchange Parameterizations Using Novel Conservative and Volatile Tracers, Global Biogeochem. Cy., 14(1), 373-387, doi:10.1029/1999GB900091, 2000.

Novakov, T. and Penner, J. E.: Large contribution of organic aerosols to cloud condensation nuclei concentrations, Nature, 365, 823-826, 1993.

Osborne, S. R., Johnson, D. W., Wood, R., Bandy, B. J., Andreae, M. O., O’Dowd, C. D., Glantz, P., Noone, K. J., Gerbig, C., Rudolph, J., Bates, T. S., and Quinn, P.: Evolution of the aerosol, cloud and boundary-layer dynamic and thermodynamic characteristics during the 2nd Langrangian experiment of ACE-2, Tellus, 52B, 275-400, 2000.

Petters, M. D. and Kreidenweis, S. M.: A single parameter representation of hygroscopic growth and cloud condensation nucleus activity, Atmos. Chem. Phys., 7, 1961-1971, doi:10.5194/acp-71961-2007, 2007.

Phillipin, S. and Betterton, E. A.: Cloud condensation nuclei measurements in southern Arizona: Instrumentation and early observations, Atmos. Res., 43, 263-275, 1997.

Pierce, J. R. and Adams, P. J.: Uncertainty in global CCN concentrations from uncertain aerosol nucleation and primary emission rates, Atmos. Chem. Phys., 9, 1339-1356, doi:10.5194/acp-91339-2009, 2009.

Pierce, J. R., Chen, K., and Adams, P. J.: Contribution of primary carbonaceous aerosol to cloud condensation nuclei: processes and uncertainties evaluated with a global aerosol microphysics model, Atmos. Chem. Phys., 7, 5447-5466, doi:10.5194/acp-75447-2007, 2007.

Pierce, J. R., Theodoritsi, G., Adams, P. J., Pandis, S. N.: Parameterization of the effect of sub-grid scale aerosol dynamics on aerosol number emission rates, J. Aerosol Sci., 40, 5, 385-393, 2009.

Pringle, K. J., Carslaw, K. S., Spracklen, D. V., Mann, G. M., and Chipperfield, M. P.: The relationship between aerosol and cloud drop number concentrations in a global aerosol microphysics model, Atmos. Chem. Phys., 9, 4131-4144, doi:10.5194/acp-94131-2009, 2009.

Quinn, P. K., Covert, D. S., Bates, T. S., Kapustin, V. N., RamseyBell, D. C., and McInnes, L. M.: Dimethylsulfide/Cloud Condensation Nuclei/Climate System: Relevant Size-Resolved Measurements of the Chemical and Physical Properties of Atmospheric Aerosol Particles, J. Geophys. Res., 98(D6), 1041110427, doi:10.1029/93JD00467, 1993.
Quinn, P. K., Bates, T. S., Baum, E., Doubleday, N., Fiore, A. M., Flanner, M., Fridlind, A., Garrett, T. J., Koch, D., Menon, S., Shindell, D., Stohl, A., and Warren, S. G.: Short-lived pollutants in the Arctic: their climate impact and possible mitigation strategies, Atmos. Chem. Phys., 8, 1723-1735, doi:10.5194/acp8-1723-2008, 2008.

Radke, L. F., Domonkos, S. V., and Hobbs, P. V.: A cloud condensation nucleus spectrometer designed for airborne measurements, J. Res. Atmos., 15, 225-229, 1981.

Ramana, M. V., Ramanathan, V., Feng, Y., Yoon, S.-C., Kim, S.-W., Carmichael, G. R., and Schauer, J. J.: Warming influenced by the ratio of black carbon to sulphate and the black carbon source, Nat. Geosci., 3, 542-545, doi:10.1038/ngeo918, 2010.

Ramanathan, V. and Carmichael, G.: Global and regional climate changes due to black carbon, Nat. Geosci., 1, 221-227, 2009.

Ramaswamy, V., Boucher, O., Haigh, J., Hauglustaine, D., Haywood, J., Myhre, G., Nakajima, T., Shi, G. Y., Solomon, S., Betts, R., Charlson, R., Chuang, C., Daniel, J. S., Del Genio, A., van Dorland, R., Feichter, J., Fuglestvedt, J., de F. Forster, P. M., Ghan, S. J., Jones, A., Kiehl, J. T., Koch, D., Land, C., Lean, J., Lohmann, U., Minschwaner, K., Penner, J. E., Roberts, D. L., Rodhe, H., Roelofs, G. J., Rotstayn, L. D., Schneider, T. L., Schumann, U., Schwartz, S. E., Schwarzkopf, M. D., Shine, K. P., Smith, S., Stevenson, D. S., Stordal, F., Tegen, I., and Zhang, Y.: Radiative forcing of climate change, in: Climate Change 2001: The Scientific Basis. Contribution of Working Group I to the Third Assessment Report of the Intergovernmental Panel on Climate Change, edited by: Joos, F. and Srinivasan, J., Cambridge University Press, Cambridge, United Kingdom and New York, NY, USA, 349-416, 2001.

Rap, A., Forster, P. M., Jones, A., Boucher, O., Haywood, J. M., Bellouin, N., and De Leon, R. R.: Parameterization of contrails in the UK Met Office Climate Model, J. Geophys. Res., 115, D10205, doi:10.1029/2009JD012443, 2010.

Reade, L., Jennings, S. G., and McSweeney, G.: Cloud condensation nuclei measurements at Mace Head, Ireland, over the period 1994-2002, Atmos. Res., 82, 610-621, 2006.

Rivera-Carpio, C. A., Corrigan, C. E., Novakov, T., Penner, J. F., Rogers, C. F., and Chow, J. C.: Derivation of contributions of sulfate and carbonaceous aerosols to cloud condensation nuclei from mass size distributions, J. Geophys. Res., 101(D14), 19483-19493, doi:10.1029/95JD01077, 1996.

Rissler, J., Swietlicki, E., Zhou, J., Roberts, G., Andreae, M. O., Gatti, L. V., and Artaxo, P.: Physical properties of the submicrometer aerosol over the Amazon rain forest during the wetto-dry season transition - comparison of modeled and measured CCN concentrations, Atmos. Chem. Phys., 4, 2119-2143, doi:10.5194/acp-4-2119-2004, 2004.

Roberts, G. and Nenes, A.: A continuous-flow streamwise thermalgradient CCN chamber for airborne measurements, Aerosol Sci. Technol., 39, 206-221, 2005.

Roberts, G. C., Andreae, M. O., Zhou, J., and Artaxo, P.: Cloud condensation nuclei in the Amazon Basin: "marine" conditions over a continent?, Geophys. Res. Lett., 28(14), 2807-2810, doi:10.1029/2000GL012585, 2001.

Roberts, G. C., P. Artaxo, J. Zhou, E. Swietlicki, and Andreae, M. O.: Sensitivity of CCN spectra on chemical and physical properties of aerosol: A case study from the Amazon Basin, J. Geophys. Res., 107(D20), 8070, doi:10.1029/2001JD000583, 2002. 
Roberts, G., Mauger, G., Hadley, O., and Ramanathan, V.: North American and Asian aerosols over the eastern Pacific Ocean and their role in regulating cloud condensation nuclei, J. Geophys. Res., 111(D13), D13205, doi:10.1029/2005JD006661, 2006.

Rose, D., Gunthe, S. S., Mikhailov, E., Frank, G. P., Dusek, U., Andreae, M. O., and Pöschl, U.: Calibration and measurement uncertainties of a continuous-flow cloud condensation nuclei counter (DMT-CCNC): CCN activation of ammonium sulfate and sodium chloride aerosol particles in theory and experiment, Atmos. Chem. Phys., 8, 1153-1179, doi:10.5194/acp-8-11532008, 2008.

Rose, D., Nowak, A., Achtert, P., Wiedensohler, A., Hu, M., Shao, M., Zhang, Y., Andreae, M. O., and Pöschl, U.: Cloud condensation nuclei in polluted air and biomass burning smoke near the mega-city Guangzhou, China - Part 1: Size-resolved measurements and implications for the modeling of aerosol particle hygroscopicity and CCN activity, Atmos. Chem. Phys., 10, 33653383, doi:10.5194/acp-10-3365-2010, 2010.

Ross, K. E., Piketh, S. J., Bruintjes, R. T., Burger, R. P., Swap, R. J., and Annegarn, H. J.: Spatial and seasonal variations in CCN distribution and the aerosol-CCN relationship over southern Africa, J. Geophys. Res., 108(D13), 8481, doi:10.1029/2002JD002384, 2003.

Rossow, W. B. and Schiffer, R. A.: Advances in understanding clouds from ISCCP, B. Am. Meteorol. Soc., 80, 2261-2288, 1999.

Rypdal, K., Rive, N., Berntsen, T. K., Klimont, Z., Mideksa, T. K., Myhre, G., and Skeie, R. B.: Costs and global impacts of black carbon abatement strategies, Tellus, 61B, 625-641, 2009.

Sato, M., Hansen, J., Koch, D., Lacis, A., Ruedy, R., Dubovik, O., Holben, B., Chin, M., and Novakov, T.: Global atmospheric black carbon inferred from AERONET, P. Natl Acad. Sci. USA, 100, 6319-6324, 2003.

Saxena, V. K. and Kassner, J. R.: Thermal-diffusion chambers as cloud-nuclei counters, Proc. Symp. Precipitation scavenging (Richland, Washington, Pacific Northwest Laboratory and US Atomic Energy Commission), 217-238, 1970.

Schulz, M., Textor, C., Kinne, S., Balkanski, Y., Bauer, S., Berntsen, T., Berglen, T., Boucher, O., Dentener, F., Guibert, S., Isaksen, I. S. A., Iversen, T., Koch, D., Kirkevåg, A., Liu, X., Montanaro, V., Myhre, G., Penner, J. E., Pitari, G., Reddy, S., Seland, Ø., Stier, P., and Takemura, T.: Radiative forcing by aerosols as derived from the AeroCom present-day and pre-industrial simulations, Atmos. Chem. Phys., 6, 5225-5246, doi:10.5194/acp-6-5225-2006, 2006.

Shantz, N. C., Chang, R. Y.-W., Slowik, J. G., Vlasenko, A., Abbatt, J. P. D., and Leaitch, W. R.: Slower CCN growth kinetics of anthropogenic aerosol compared to biogenic aerosol observed at a rural site, Atmos. Chem. Phys., 10, 299-312, doi:10.5194/acp10-299-2010, 2010.

Shinozuka, Y., Clarke, A. D., DeCarlo, P. F., Jimenez, J. L., Dunlea, E. J., Roberts, G. C., Tomlinson, J. M., Collins, D. R., Howell, S. G., Kapustin, V. N., McNaughton, C. S., and Zhou, J.: Aerosol optical properties relevant to regional remote sensing of $\mathrm{CCN}$ activity and links to their organic mass fraction: airborne observations over Central Mexico and the US West Coast during MILAGRO/INTEX-B, Atmos. Chem. Phys., 9, 6727-6742, doi:10.5194/acp-9-6727-2009, 2009.

Sihto, S.-L., Kulmala, M., Kerminen, V.-M., Dal Maso, M., Petäjä,
T., Riipinen, I., Korhonen, H., Arnold, F., Janson, R., Boy, M., Laaksonen, A., and Lehtinen, K. E. J.: Atmospheric sulphuric acid and aerosol formation: implications from atmospheric measurements for nucleation and early growth mechanisms, Atmos. Chem. Phys., 6, 4079-4091, doi:10.5194/acp-6-4079-2006, 2006.

Snider, J. R. and Brenguier, J.-L.: Cloud condensation nuclei and cloud droplet measurements during ACE-2, Tellus, 52B, 828842, 2000.

Spracklen, D. V., Pringle, K. J., Carslaw, K. S., Chipperfield, M. P., and Mann, G. W.: A global off-line model of sizeresolved aerosol microphysics: I. Model development and prediction of aerosol properties, Atmos. Chem. Phys., 5, 22272252, doi:10.5194/acp-5-2227-2005, 2005.

Spracklen, D. V., Carslaw, K. S., Kulmala, M., Kerminen, V.-M., Mann, G. W., and Sihto, S.-L.: The contribution of boundary layer nucleation events to total particle concentrations on regional and global scales, Atmos. Chem. Phys., 6, 5631-5648, doi:10.5194/acp-6-5631-2006, 2006.

Spracklen, D. V., Pringle, K. J., Carslaw, K. S., Mann, G. W., Manktelow, P., and Heintzenberg, J.: Evaluation of a global aerosol microphysics model against size-resolved particle statistics in the marine atmosphere, Atmos. Chem. Phys., 7, 20732090, doi:10.5194/acp-7-2073-2007, 2007.

Spracklen, D. V., Carslaw, K. S., Kulmala, M., Kerminen, V.-M., Sihto, S.-L., Riipinen, I., Merikanto, J., Mann, G. W., Chipperfield, M. P., Wiedensohler, A., Wolfram Birmili, W., and Lihavainen, H.: Contribution of particle formation to global cloud condensation nuclei concentrations, Geophys. Res. Lett., 35, L06808, doi:10.1029/2007GL033038, 2008a.

Spracklen, D. V., Arnold, S. R., Carslaw, K. S., Sciare, J., and Pio, C.: Globally significant oceanic source of organic carbon aerosol, Geophys. Res. Lett., 35, L12811, doi:10.1029/2008GL033359, 2008b.

Spracklen, D. V., Carslaw, K. S., Merikanto, J., Mann, G. W., Reddington, C. L., Pickering, S., Ogren, J. A., Andrews, E., Baltensperger, U., Weingartner, E., Boy, M., Kulmala, M., Laakso, L., Lihavainen, H., Kivekäs, N., Komppula, M., Mihalopoulos, N., Kouvarakis, G., Jennings, S. G., O’Dowd, C., Birmili, W., Wiedensohler, A., Weller, R., Gras, J., Laj, P., Sellegri, K., Bonn, B., Krejci, R., Laaksonen, A., Hamed, A., Minikin, A., Harrison, R. M., Talbot, R., and Sun, J.: Explaining global surface aerosol number concentrations in terms of primary emissions and particle formation, Atmos. Chem. Phys., 10, 4775-4793, doi:10.5194/acp-10-4775-2010, 2010.

Stier, P., Feichter, J., Kinne, S., Kloster, S., Vignati, E., Wilson, J., Ganzeveld, L., Tegen, I., Werner, M., Balkanski, Y., Schulz, M., Boucher, O., Minikin, A., and Petzold, A.: The aerosolclimate model ECHAM5-HAM, Atmos. Chem. Phys., 5, 11251156, doi:10.5194/acp-5-1125-2005, 2005.

Ten Hoeve, J. E., Remer, L. A., and Jacobson, M. Z.: Microphysical and radiative effects of aerosols on warm clouds during the Amazon biomass burning season as observed by MODIS: impacts of water vapor and land cover, Atmos. Chem. Phys., 11, 3021-3036, doi:10.5194/acp-11-3021-2011, 2011.

van der Werf, G. R., Randerson, J. T., Collatz, G. J., Giglio, L., Kasibhatla, P. S., Arellano, A. F., Olsen, S. C., and Kasischke, E. S.: Continental-scale partitioning of fire emissions during the 1997 to $2001 \mathrm{El} \mathrm{Nino/La} \mathrm{Nina} \mathrm{period,} \mathrm{Science,} \mathrm{303(5654),} \mathrm{73-76,}$ 
2004.

Unger, N., Bond, T. C., Wang, J. S., Koch, D. M., Menon, S., Shindell, D. T., and Bauer, S.: Attribution of climate forcing to economic sectors, P. Natl. A Sci., 107(8), 3382-3387, 2010.

VanReken, T. M., Rissman, T. A., Roberts, G. C., Varutbangkul, V., Jonsson, H. H., Flagan, R. C., and Seinfeld, J. H.: Toward aerosol/cloud condensation nuclei $(\mathrm{CCN})$ closure during CRYSTAL-FACE, J. Geophys. Res., 108(D20), 4633, doi:10.1029/2003JD003582, 2003.

Vestin, A., Rissler, J., Swietlicki, R., Frank, G. P., and Andreae, M. O.: Cloud-nucleating properties of the Amazonian biomass burning aerosol: Cloud condensation nuclei measurements and modelling, J. Geophys. Res., 112(D14), D14201, doi:10.1029/2006JD008104, 2007.

Wang, M. and Penner, J. E.: Aerosol indirect forcing in a global model with particle nucleation, Atmos. Chem. Phys., 9, 239-260, doi:10.5194/acp-9-239-2009, 2009.

Wang, J., Lee, Y.-N., Daum, P. H., Jayne, J., and Alexander, M. L.: Effects of aerosol organics on cloud condensation nucleus (CCN) concentration and first indirect aerosol effect, Atmos. Chem. Phys., 8, 6325-6339, doi:10.5194/acp-8-6325-2008, 2008.

Weare, B. C.: Near-Global Observations of Low Clouds, J. Climate, 13, 1255-1268, 2000.

Williams, E., Rosenfeld, D., Madden, N., Gerlach, J., Gears, N., Atkinson, L., Dunnemann, N., Frostrom, G., Antonio, M., Biazon, B., Camargo, R., Franca, H., Gomes, A., Lima, M., Machado, R., Manhaes, S., Nachtigall, L., Piva, H., Quintiliano, W., Machado, L., Artaxo, P., Roberts, G., Renno, N., Blakeslee, R., Bailey, J., Boccippio, D., Betts, A., Wolff, D., Roy, B., Halverson, J., Rickenbach, T., Fuentes, J., and Avelino, E.: Contrasting convective regimes over the Amazon: Implications for cloud electrification, J. Geophys. Res., 107(D20), 8082, doi:10.1029/2001JD000380, 2002.
Wood, R., Johnson, D., Osborne, S., Andreae, M. O., Bandy, B., Bates, T. S., O’Dowd, C., Glantz, P., Noone, K., Quinn, P. K., Rudolph, J., and Suhre, K.: Boundary Layer and aerosol evolution during the 3rd Lagrangian experiment of ACE-2, Tellus, 52B, 401-422, 2000.

Yoon, Y. J., Ceburnis, D., Cavalli, F., Jourdan, O., Putaud, J. P., Facchini, M. C., Decesari, S., Fuzzi, S., Sellegri, K., Jennings, S. G., and O'Dowd, C. D.: Seasonal characteristics of the physicochemical properties of North Atlantic marine atmospheric aerosols, J. Geophys. Res., 112, D04206, doi:10.1029/2005JD007044, 2007.

Yum, S. S. and Hudson, J.: Vertical distributions of cloud condensation nuclei spectra over the springtime Arctic Ocean, J. Geophys. Res., 106(D14), 15045-15052, doi:10.1029/2000JD900357, 2001.

Yum, S. S. and Hudson, J. G.: Maritime/continental microphysical contrasts in stratus, Tellus, 52B, 61-73, 2002.

Yum, S. S. and Hudson, J. G.: Wintertime/summertime contrasts of cloud condensation nuclei and cloud microphysics over the Southern Ocean, J. Geophys. Res., 109(D6), D06204, doi:10.1029/2003JD003864, 2004.

Yum, S. S., Hudson, J. G., Song, K. Y., and Choi, B.-C.: Springtime cloud condensation nuclei concentrations on the west coast of Korea, Geophys. Res. Lett., 32(9), L09814, doi:10.1029/2005GL022641, 2005.

Yum, S. S., Roberts, G., Kim, J. H., Song, K., and Kim, D.: Submicron aerosol size distributions and cloud condensation nuclei concentrations measured at Gosan, Korea, during the Atmospheric Brown Clouds-East Asian Regional Experiment 2005, J. Geophys. Res., 112(D22), D22S32, doi:10.1029/2006JD008212, 2007. 